\title{
Essay
}

\section{Reconsidering Shaw: The Miranda of Race-Conscious Districting}

\author{
Melissa L. Saunders ${ }^{\dagger}$
}

In Shaw v. Reno (Shaw I) ${ }^{1}$ and its progeny, the United States Supreme Court relied upon the Equal Protection Clause of the Fourteenth Amendment to impose limits on race-conscious districting. In Shaw, the Court held that five North Carolina voters had stated a claim under the Equal Protection Clause in alleging that the state's congressional redistricting plan contained districts shaped so dramatically irregular that they could only be viewed as having been drawn along racial lines. ${ }^{2}$ In a series of subsequent cases, the Court developed an elaborate framework for the adjudication of these Shaw claims. ${ }^{3}$ Under that framework, the plaintiff's initial burden is to show, using direct or circumstantial evidence or a combination of both, that the state used race as the "predominant factor" in the design of the challenged district, "subordinat[ing] traditional

$\dagger$ Professor of Law, University of North Carolina. For helpful comments on earlier drafts, I thank Lou Bilionis, Caroline Brown, Hampton Dellinger, Bill Eskridge, Sam Issacharoff, John Jeffries, Eric Muller, Rick Pildes, Bob Saunders, and Larry Zelenak. For excellent research assistance, I thank Kathy Murphy.

1. 509 U.S. 630 (1993).

2. See id. at 642,658 . The plan contained two districts that were highly imegular in shape: District 1, a majority-black district that had been described as resembling a "Rorschach ink-blot test" or a "bug splattered on a windshield," id. at 635, and District 12, a majority-black district that the Court described as "wind[ing] in snakelike fashion." id, for nearly 160 miles along Interstate 85, often no wider than the highway itself, so that "[i]f you drove down the interstate with both car doors open, you'd kill most of the people in [it]." id. at 636 (quoting a state legislator). The voters who challenged the plan, all of whom were white, claimed that it violated their constitutional "right" to participate in a colorblind electoral process. See id. at $641-42$.

3. See Bush v. Vera, 517 U.S. 952, 958-65 (1996) (plurality opinion): Shaw v. Hunt (Shaw II), 517 U.S. 899, 905-07 (1996); Miller v. Johnson, 515 U.S. 900, 916 (1995). 
race-neutral districting principles... to racial considerations." ${ }^{4}$ If the plaintiff makes this showing, the plan is subject to strict scrutiny and will be held unconstitutional unless the state demonstrates that its use of race was "narrowly tailored to achieve a compelling interest." 's Applying this framework, the Court has declared unconstitutional a number of "safe" districts created for racial minorities after the 1990 census. ${ }^{6}$

From the beginning, critics have charged that the limitations on raceconscious districting set forth in Shaw and its progeny have no foundation in the Equal Protection Clause. Justice White has accused the Court of "imagining an entirely new cause of action" " that "the Constitution does not justify, much less mandate." 8 Justice Stevens has charged the Court with having invented a new right-a "right to color-blind districting" - that has "no basis" in the Constitution. ${ }^{9}$ Justice Breyer has said that he "do[es] not believe that the Constitution embodies the doctrine that the majority enunciates." 10 With these criticisms have come predictable allegations that an activist Court has improperly invoked the Constitution to justify imposing its own policy preferences on the nation."

These criticisms cannot easily be dismissed. While the Court's new limitations on race-conscious districting may make good sense as a matter

4. Miller, 515 U.S. at 916 . The Court describes the "traditional race-neutral districting principles" to which it refers as "including but not limited to compactness, contiguity, and respect for political subdivisions or communities defined by actual shared interests." $I d$.

5. Id. at 920 . The Court has held that remedying the effects of past or present racial discrimination may, in a proper case, be a compelling state interest. See Shaw 11,517 U.S. at 90910. It has assumed, without deciding, that compliance with the Voting Rights Act, as it has been interpreted by the Court, may also be a compelling state interest. See Vera, 517 U.S. at 976-77 (plurality opinion); Shaw II, 517 U.S. at 911 ; Miller, 515 U.S. at 920-21.

6. See Vera, 517 U.S. 952 (plurality opinion) (invalidating three majority-minority congressional districts in Texas, two majority-black and the third majority-Hispanic); Shaw II. 517 U.S. 899 (invalidating a majority-black congressional district in North Carolina); Miller, 515 U.S. 900 (invalidating two majority-black congressional districts in Georgia).

7. Shaw I, 509 U.S. 630, 659 (1993) (White. J., dissenting).

8. Id. at 674 .

9. Shaw II, 517 U.S. at 925 (Stevens, J., dissenting); see also Vera, 517 U.S. at 1041 (Stevens, J., dissenting) (asserting that " nothing in the Constitution requires this unnecessary intrusion into the ability of States to negotiate solutions to political differences while providing long-excluded groups the opportunity to participate effectively in the democratic process").

10. Abrams v. Johnson, 521 U.S. 74, 119 (1997) (Breyer, J., dissenting).

11. See, e.g., David Kairys, Race Trilogy, 67 TEMP. L. REv. 1, 12 (1994) (accusing the Court of "judicial activism"); Pamela S. Karlan, Still Hazy After All These Years: Voting Rights in the Post-Shaw Era, 26 CuMB. L. REv. 287, 311 (1996) (accusing the Court of improperly invoking the Constitution to justify "impos[ing] its own vision of democratic theory" on the nation); $\mathrm{J}$. Morgan Kousser, Shaw v. Reno and the Real World of Redistricting and Representation, 26 RUTGERS L.J. 625, 648 (1995) (accusing the Court of " disregard[ing] the conservative tradition of judicial restraint"); Jamin Raskin \& Thomas Goldstein, Turning the Voting Rights Act on Its Head, L.A. TIMES, Sept. 4, 1994, at M5 (describing Shaw as an "outburst of judicial activism by the court's conservatives"); Jeffrey Rosen, The Color-Blind Court, NEW REPUBLIC, July 31. 1995, at 19 (criticizing the Court for its "judicial activism"). 
of public policy, ${ }^{12}$ the Court has yet to provide a convincing explanation for them as principles of constitutional law. Indeed, the Court seems deeply uncertain about the precise nature of the constitutional wrong that it is attempting to redress in these cases. ${ }^{13}$ This basic conceptual uncertainty, together with a series of unexplained doctrinal quirks, has confused and confounded the state officials and lower-court judges who labor with the doctrine at the ground level. The Shaw doctrine, it seems, is not only inconsistent with the Court's traditional equal protection jurisprudence, but is also simply incomprehensible.

Despite these difficulties, Shaw's limitations on race-conscious districting seem destined to stay, at least for the foreseeable future. Ignoring the complaints of the dissenting Justices and a flood of critical commentary from the academy, the five-member majority that decided Shaw has now applied its rule in nearly a dozen cases. ${ }^{\text {is }}$ While that majority remains deeply divided about Shaw's implications, ${ }^{15}$ it shows no signs of

12. To be sure, there is powerful empirical evidence that racial-bloc voting remains pervasive, at least in the South, and that it continues to make it very difficult for minority candidates to win election to any legislative office-local, state, or national-in districts that are majority-white. See DAVID LUBLIN, THE PARADOX OF REPRESENTATION: RACIAL GERRYMANDERING AND MINORITY INTERESTS IN CONGRESS 39-5.4 (1997): QUIET REVOLUTION IN THE SOUTH: THE IMPACT OF THE VOTING RIGHTS ACT. 1965-1990, at 311, 336-39, 345 (Chandler Davidson \& Bernard Grofman eds., 1994); David Lublin, The Elecrion of African Americans and Latinos to the U.S. House of Representatives, 1972-1994. 25 AN. POL. Q. 269. 271-85 (1997). Nonetheless, there are good reasons for persons of all ideological persuasions to think that race-conscious districting may not be a wise way to deal with this problem. For one thing, race-conscious districting may do more to exacerbate existing palterns of racially polarized voting than to eradicate them. See Shaw 1, 509 U.S. at 647-48 (asserting that race-conscious districting "may exacerbate the very patterns of racial bloc voting that [it] is sometimes said to counteract" by "reinforc[ing] the perception that members of the same racial group ... think alike, share the same political interests, and will prefer the same candidates at the polls"). Furthermore, there is some empirical evidence that the creation of "safe" districts for racial minorities may make legislative bodies as a whole less responsive to the substantive political interests of those minorities. See LUBLIN, supra, at 99; Charles Cameron et al. Do MajorityMinority Districts Maximize Substantive Black Representation in Congress?, 90 AM. POL. SCI. REV. 794, 807-08 (1996). For these reasons, it may well be desirable, as a matter of public policy. to impose strict legal constraints on the practice of race-conscious districting. even though it aims to ameliorate the profound and persistent problem of minority exclusion from our political processes.

13. For a careful exploration of this conceptual uncertainty and the fault lines that lic beneath it, see Samuel Issacharoff \& Thomas C. Goldstein, Identifying the Ham in Racial Gerrymandering Claims, 1 MICH. J. RACE \& L. 47 (1996).

14. Eight of these cases have received plenary consideration. See Hunt v. Cromartic, 526 U.S. 541 (1999); Lawyer v. Deparment of Justice, 521 U.S. 567 (1997); Abrams, 521 U.S. 74; Vera. 517 U.S. 952 (plurality opinion); Shaw II, 517 U.S. 899; Miller v. Johnson. 515 U.S. 900 (1995); United States v. Hays, 515 U.S. 737 (1995); Shaw I, 509 U.S. 630. The rest have been decided summarily. See Quilter v. Voinovich, 523 U.S. 1043 (1998) (mem.), affg 981 F. Supp. 1032 (N.D. Ohio 1997); DeWitt v. Wilson, 515 U.S. 1170 (1995) (mem.), aff 856 F. Supp. 1409 (E.D. Cal. 1994).

15. For example, Justice O'Connor asserts that Shaw' does not require the application of strict scrutiny to majority-minority districts that, though intentionally created, are drawn in substantial compliance with certain traditional districting principles. See Vera. 517 U.S. at 958-59. 962 (plurality opinion); id. at 993 (O'Connor, J., concurring). By contrast, Justices Scalia and Thomas, 
abandoning its holding, ${ }^{16}$ and even the dissenting Justices now concede that "the Court seems settled in its conclusion that racial gerrymandering claims such as these may be pursued." ${ }^{17}$ That being the case, it is time, as Rick Pildes has said, for academic commentators to stop their "unproductiv[e]" efforts to convince the Court to overturn Shaw and concentrate instead on trying to understand it "on its own terms." 18

In this Essay, I want to suggest one way in which we might begin to do that: by considering the possibility that the limitations on race-conscious districting set forth in Shaw and its progeny are much like the limits that Miranda v. Arizona ${ }^{19}$ imposed upon police interrogation of suspects in custody. That is, they are a "prophylactic" measure that overprotects individual constitutional rights in some cases in order to ensure adequate protection of those rights across a range of cases. Prophylactic rules of this sort have been a familiar, if somewhat controversial, feature of the Court's work in other areas of constitutional law. ${ }^{20}$ Both the law of constitutional criminal procedure and that of the First Amendment are full of rules that can be characterized as prophylactic in nature. ${ }^{21}$ Nor are prophylactic rules unheard of in equal protection law-the strict scrutiny of classical equal protection doctrine, for example, can be seen as a prophylactic rule. ${ }^{22}$ Shaw and its progeny, I suggest, are simply the latest example of a phenomenon that is pervasive in our constitutional law.

In suggesting that Shaw is like Miranda, I do not mean to damn it by association; I take no position on the longstanding debate over the Court's authority to craft overbroad prophylactic rules to enforce the Constitution. ${ }^{23}$ But I do mean to suggest that those who believe Miranda to be a legitimate

and probably Justice Kennedy, believe that it does. See id. at 999-1003 (Thomas, J., concurring in the judgment); id. at 996 (Kennedy, J., concurring) (applying strict scrutiny, but not reaching Justice O'Connor's broader views on the application of strict scrutiny).

16. Indeed, the majority has taken to dismissing with obvious irritation the dissenters' arguments that Shaw should be overturned. See, e.g., Vera, 517 U.S. at 983-84 (plurality opinion); Shaw II, 517 U.S. at 904 n.2.

17. Vera, 517 U.S. at 1009 n.7 (Stevens, J., dissenting).

18. Richard H. Pildes, Principled Limitations on Racial and Partisan Redistricting, 106 YALE L.J. 2505, 2509 (1997).

19. 384 U.S. 436 (1966).

20. The classic here is David A. Strauss, The Ubiquity of Prophylactic Rules, 55 U. CHI. L. REV. 190 (1988). For further discussion, see Daryl J. Levinson, Rights Essentialism and Remedial Equilibration, 99 COLUM. L. REV. 857, 899-904 (1999); and Stephen J. Schulhofer, Reconsidering Miranda, 54 U. CHI. L. REV. 435, 448-53 (1987). Levinson argues that prophylactic rules are such a pervasive feature of our constitutional law that attempting to distinguish the "core" of a constitutional right from its "prophylactic periphery" is "both hopeless and pointless." Levinson, supra, at 900.

21. For some concrete examples, see Levinson, supra note 20, at 902-04; and Strauss, supra note 20 , at $195-204$.

22. See Strauss, supra note 20 , at 204-07.

23. For the argument that the Court lacks the constitutional power to do this, see Joseph D. Grano, Prophylactic Rules in Criminal Procedure: A Question of Article III Legitimacy, $80 \mathrm{Nw}$. U. L. REV. 100 (1985). For an argument to the contrary, see Strauss, supra note 20. 
exercise of the Court's authority have no business arguing that Shaw is illegitimate and, conversely, that those who believe Shaw to be legitimate have no business arguing that Miranda is not. For this reason, the debate over Shaw's legitimacy could have important implications for the challenge to Miranda that looms on the Court's horizon. ${ }^{24}$

Part I of this Essay explains why Shaw's critics believe that the limitations that the case imposes on race-conscious districting lack any real basis in the Equal Protection Clause. The essential problem, in their view, is that Shaw permits courts to declare laws "unconstitutional" under the Clause in the absence of any proof that they subject any identifiable class of persons to a special disadvantage. Because a showing that the challenged law has such a "discriminatory effect" on a discrete class has always been thought to be an essential element of an equal protection claim, they assert, Shaw and its progeny represent a substantial extension of existing doctrine, an extension that the Court has failed even to acknowledge, much less to justify.

Part II of the Essay considers the possibility that the Court is using these cases to effect a major change in its equal protection jurisprudence: declaring that the Equal Protection Clause forbids the state to use race in dealing with people, absent truly extraordinary justification, even when it is not subjecting any identifiable class of persons to any special disadvantage. While I concede that this may explain the votes cast by some members of the Shaw majority, I conclude that it cannot explain the Shaw doctrine itself, as it is currently constituted.

Part III offers an alternative explanation for the Court's failure to require proof of special disadvantage to an identifiable class of persons in these cases. I argue that the Court is applying an overbroad per se rule much like the one it applies in Miranda. This Part begins with a brief review of Miranda's per se rule and the justification that the Court has given for it. It then seeks to demonstrate that Shaw and its progeny can be explained on similar grounds. So understood, I argue, the doctrine that the Court has constructed here is neither as radical nor as incoherent as its critics have maintained. But it is too imprecise to be workable, and the Court needs to rectify this problem if the doctrine is to realize its full potential. Part III offers some ideas about how this might be accomplished.

The Essay concludes with some brief thoughts on the implications of this reading of Shaw.

24. See United States v. Dickerson, 166 F.3d 667 (4th Cir.) (holding that Congress has the power to bypass the requirements of Miranda with ordinary legislation, and that it has done so in 18 U.S.C. § 3501 (1994)), cert. granted, 120 S. Cl. 578 (1999). For a discussion of Dickerson and the possibility that the Court will use it to reconsider or overnule Miranda, see Roger Parloff, Miranda on the Hot Seat, N.Y. TIMES, Sept. 26, 1999, § 6 (Magazine), at 84. 


\section{THE PROBLEM WITH SHAW}

From the beginning, the Court has characterized Shaw's limitations on race-conscious districting as a routine application of longstanding principles of its equal protection jurisprudence. The Court's logic, first set forth in Justice O'Connor's opinion in Shaw I and reiterated in each of its progeny, goes as follows: The Equal Protection Clause requires courts to apply strict scrutiny to all laws that classify persons on the basis of their race. ${ }^{25} \mathrm{An}$ electoral districting plan that draws lines on the basis of race is a law that "classifies" persons by race. ${ }^{26}$ It therefore follows inexorably that such a law must be subject to strict scrutiny. ${ }^{27}$ To the extent that the lower courts have read the plurality opinion in United Jewish Organizations $v$. Carey ${ }^{28}$ as suggesting that race-conscious districting plans adopted with the "benign" purpose of giving effect to minority voting strength are exempt from these principles, ${ }^{29}$ they have erred.

At first glance, this looks like a straightforward application of the "suspect classification" strand of traditional equal protection doctrine. If one looks beyond rhetoric to reality, though, it reveals itself to be a substantial - and unexplained-extension of that doctrine. Strict scrutiny, it must be remembered, is not a substantive rule of law that the Court has derived from the Equal Protection Clause, but a framework it has erected for the adjudication of equal protection claims, a framework designed to help courts identify violations of equal protection rights. ${ }^{30}$ Traditional equal

25. See Miller v. Johnson, 515 U.S. 900, 904-05 (1995); Shaw I, 509 U.S. 630, 642-44 (1993).

26. Justice O'Connor's opinion for the Court in Shaw I describes race-conscious districting laws as "laws that classify citizens by race," 509 U.S. at 644. as "legislation classifying citizens by race," id. at 646 , as laws that "classify voters on the basis of race," id. at 649 , and as "[r]acial classifications with respect to voting," id. at 657 . Later cases in the Shaw line adhere to this characterization. See, e.g., Hunt v. Cromartie, 119 S. Ct. 1545, 1548-49 (1999) (describing "racially gerrymandered districting schemes" as "laws that classify citizens on the basis of race”); Bush v. Vera, 517 U.S. 952, 1001 (1996) (Thomas, J., concurring) (describing raceconscious districting laws as "racial classifications"); Shaw II, 517 U.S. 899, 904 (1996) (describing "racially gerrymandered districting scheme[s]" as "laws that classify citizens on the basis of race"); Miller, 515 U.S. at 910 (describing race-conscious districting laws as the "deliberate classification of voters on the basis of race").

Of course, as the Court concedes, these laws do not explicitly classify by race; indeed. they do not mention race at all. See Cromartie, 119 S. Ct. at 1549 ("Districting legislation ordinarily... is race-neutral on its face."). But the Court characterizes them as racial classifications of the "covert" variety: facially race-neutral laws that are intended to have, and do have, the effect of classifying citizens by race. See id.; Miller, 515 U.S. at 905 (citing Village of Arlington Heights v. Metropolitan Hous. Dev. Corp., 429 U.S. 252, 266 (1977)); Shaw l, 509 U.S. at $642-44$ (same).

27. See Cromartie, 119 S. Ct. at 1549; Vera, 517 U.S. at 984 (plurality opinion); Miller. 515 U.S. at 904-05; Shaw I, 509 U.S. at 644.

28. 430 U.S. 144 (1977).

29. See Miller, 515 U.S. at 914-15; Shaw 1, 509 U.S. at 651-52.

30. For the classic explanation, see Joseph Tussman \& Jacobus tenBroek. The Equal Protection of the Laws, 37 CAL. L. REv. 341 (1949). For more recent commentary to the same 
protection doctrine is based on the premise that a law must subject an identifiable class of persons to some special disadvantage in order to be challengeable under the Equal Protection Clause. ${ }^{31}$ It is the imposition of this special disadvantage that must, according to the traditional understanding, be justified by reference to an adequate public purpose if the law is to survive an equal protection challenge. ${ }^{32}$ When strict scrutiny is triggered, ${ }^{33}$ this special disadvantage must be shown to be narrowly tailored to promote a compelling state interest.

effect, see, for example, JOHN HART ELY, DEMOCRACY AND DISTRUST: A THEORY OF JUDICIAL REVIEW 147 (1980); Robert W. Bennet,. "Mere" Rationality in Constimutional Law: Judicial Review and Democratic Theon; 67 CAL. L. Rev. 1049, 1077 (1979): Michacl J. Perry, Modem Equal Protection: A Conceptualization and Appraisal, 79 COLUM. L. REV. 1023. 1033-36 (1979): and Cass R. Sunstein, Public Values, Private Interests, and the Equal Protection Clause, 1982 SUP. CT. REV. 127, 140-43.

31. See Melissa L. Saunders, Equal Protection, Class Legislation, and Colorblindness, 96 MICH. L. REv. 245, 245 (1997). As every student of modern equal protection law knows, Washington v. Davis and its progeny impose a further requirement: a showing that the state has "intentionally" or "purposefully" subjected the plaintiff to this special disadvantage. Washington v. Davis, 426 U.S. 229, 239-40 (1976); see also Village of Arlington Heights, 429 U.S. at 265. As I have explained elsewhere, however, they do not purport to relieve the plaintiff of the obligation to show that the law does in fact subject him to that special disadvantage. See Saunders, supra, at 308-09.

32. Of course, most laws can be characterized as subjecting some class of persons to some sort of special disadvantage, and so most can be challenged under the Equal Protection Clause. To prevent the Clause from authorizing constant judicial second-guessing of the policy judgments of elected state officials, the Cour has directed reviewing cours to apply cernin presumptions in adjudicating equal protection claims. In most cases, they are to apply a strong presumption that the special disadvantage serves a legitimate public purpose, a presumption that the challenger can overcome only by demonstrating that the classification cannot "rationally" be said to further any "legitimate" governmental purpose. Sce, e.g., Heller v. Doc, 509 U.S. 312, 319-20 (1993); Pennell v. City of San Jose, 485 U.S. I, 14 (1988); United States R.R. Retirement Bd. v. Fritz 449 U.S. 166, 175-77 (1980); Personnel Adm'r v. Feeney, 442 U.S. 256. $272-73$ (1979). In certain situations in which it is very likely that the special disadvantage does not serve a legitimate public purpose, however, courts are to abandon the usual presumption of validity and take a closer look. See Feeney, 442 U.S. at 272-73. In some situations, this closer look takes the form of "strict scrutiny," in which the court applies a strong presumption that the special disadvantage does not serve a legitimate public purpose, a presumption that the state can overcome only by demonstrating that it is "necessary" to achieve a "compelling" govermmental purpose. See. e.g., City of Richmond v. J.A. Croson Co., 488 U.S. 469. $493-94$ (1989) (applying the suspectclassification strand); id. at 520 (Scalia, J., concurring in the judgment); Harper v. Virginia Bd. of Elections, 383 U.S. 663, 670 (1966) (applying the fundamental-rights strand).

33. Strict scrutiny is triggered by a showing that the state has used a "suspect" criterion like race to select the class of persons upon whom the special disadvantage will be imposed. See, e.g., Croson, 488 U.S. at 493-94; id. at 520 (Scalia. J., concurring in the judgment). in this context, the directive to apply more exacting scrutiny reflects the intuition that the real reason for the state's decision to impose a special disadvantage on that class is very likely to be impermissible animus. See, e.g., Palmore v. Sidoti, 466 U.S. 429, 432 (1984) ("Classifying persons according to their race is more likely to reflect racial prejudice than legitimate public concerns ...."); Feeney, 442 U.S. at 272 (asserting that racial classifications "supply a reason to infer antipathy" (quoting Vance v. Bradley, 440 U.S. 93, 97 (1979))). Requiring the state to demonstrate that imposition of the special disadvantage is "necessary" to achieve a "compelling" state interest serves is a way of "smoking out" impermissible animus that the state may be concealing behind pretextual public purpose justifications. See ELY, supra note 30, at 146; Jed Rubenfeld, Affirmarive Acrion, 107 YALE L.J. 427, 436-37 (1997). 
The difficulty with Shaw and its progeny, from the standpoint of traditional equal protection jurisprudence, is that these cases permit courts to declare laws unconstitutional under the Equal Protection Clause in the absence of evidence that the laws subject any identifiable class of persons to special disadvantage. ${ }^{34}$ This quirk was not immediately apparent from the Court's opinion in Shaw I. To be sure, as the dissenters pointed out, the Shaw plaintiffs did not allege or prove that they were being subjected to the kind of special disadvantage that usually forms the basis of an equal protection challenge to district lines-dilution of their voting strength. ${ }^{35}$ But their case came to the Court on appeal from a dismissal for failure to state a claim, ${ }^{36}$ and their complaint, generously viewed, could be read to allege that the plan subjected them to a special disadvantage of another kindspecifically, to some sort of special "stigmatic" or "representational" harm. ${ }^{37}$ Because Justice O'Connor's opinion for the Court held only that their allegations were sufficient to state a claim, ${ }^{38}$ and because it relied specifically on the possibility that the law might inflict these special stigmatic or representational harms to explain why that claim was cognizable under the Equal Protection Clause ${ }^{39}$ the Court did not foreclose the possibility that the plaintiffs would be required to prove at trial that they had suffered special disadvantage. ${ }^{40}$

34. The problem can also be characterized as one of standing to sue, and Shaw's critics have often done so. See, e.g., Pamela S. Karlan, All Over the Map: The Supreme Court's Voting Rights Trilogy, 1993 SUP. CT. REV. 245, 278-80 (asserting that the Shaw plaintiffs lacked Article III standing to challenge North Carolina's congressional redistricting in federal court because they did not allege that it had caused them to suffer an individualized "injury in fact"); Karlan, supra note 11, at 289-99 (same); Frank R. Parker, The Constitutionality of Racial Redistricting: A Critique of Shaw v. Reno, 3 D.C. L. REV. 1, 9-22 (1995) (same); see also Shaw II, 517 U.S. 899. 918, 923 n.3 (1996) (Stevens, J., dissenting) (asserting that the plaintiffs lacked standing to sue because they had not alleged any legally cognizable injury); Miller v. Johnson, 515 U.S. 900, 929 (1995) (Stevens, J., dissenting) (same); United States v. Hays, 515 U.S. 737, 750-52 (1995) (Stevens, J., concurring in the judgment) (same). But it is also, and more fundamentally, one that goes to the validity of the plaintiffs' claim on the merits, since a showing that the plaintiffs have been subjected to some special disadvantage is an essential-indeed, the most essential-clement of the constitutional claim they are asserting. Cf. Samuel Issacharoff \& Pamela S. Karlan. Standing and Misunderstanding in Voting Rights Law, 111 HARV. L. REV. 2276, 2292 (1998) (asserting that the "hard question" here is not "who can sue" but how the Constitution plausibly can be interpreted to forbid the race-based districting practices at which Shaw and its progeny strike).

35. See Shaw I, 509 U.S. 630, 666-67 (1993) (White, J., dissenting); id. at 682 (Souter, J., dissenting).

36. See id. at 638-39.

37. See Complaint at 7, Shaw v. Barr (E.D.N.C. Mar. 12, 1992) (No. 92-202). But see Shaw I, 509 U.S. at 686 n.9 (Souter, J., dissenting) (asserting that "the complaint nowhere alleges any type of stigmatic harm").

38. See Shaw I, 509 U.S. at 658.

39. See id. at 649-50.

40. Seizing upon this ambiguity, the defendant-intervenors in Shaw, on remand from the Court's decision in Shaw I, argued that the plaintiffs could not prevail at trial without proving that they had suffered special stigmatic or representational harm. See Shaw v. Hunt, 861 F. Supp. 408, 423-24 (E.D.N.C. 1994), rev'd on other grounds, 517 U.S. 899 (1996). 
The Court's decision in Miller v. Johnson, however, quickly dispelled this notion. There, the Court affirmed a district court's holding that a raceconscious districting scheme was unconstitutional under Shaw in the absence of any finding that it had caused any identifiable class of persons to suffer either of the "special harms" mentioned in Shaw," much less any other kind of special disadvantage. The implication of the Court's decision was hard to avoid: A plaintiff may prevail on a Shaw claim without producing any evidence that the challenged law actually subjects any identifiable class of persons to special disadvantage. ${ }^{42}$ That in turn seemed, to many observers, to represent a substantial extension of traditional equal protection jurisprudence, for the Court had never before invoked the Equal Protection Clause to strike down a law without finding that it subjected some group to special disadvantage. ${ }^{43}$

The extension did not go unnoticed by the Court itself. In lengthy dissents in the two Shaw cases decided the following Term, Justices Stevens and Souter drew attention to it. ${ }^{4}$ Dissenting in Shaw v. Hunt (Shaw II), Justice Stevens wrote,

Even if an objection to a State's decision to forgo color-blind districting is cognizable under some constitutional provision, I do not understand why that provision should be the Equal Protection Clause....

... [T] he Equal Protection Clause ... protects against wrongs which by definition burden some persons but not others.

Here ... it appears that no individual has been burdened more than any other. The supposedly insidious messages that Shaw I contends will follow from extremely irregular race-based districting

41. See Miller v. Johnson, 515 U.S. 900 (1995). In Miller, neither the district court nor the Supreme Court made any finding that the plaintiffs had suffered special stigmatic or representational harm. See Karlan, supra note 11, at 296. Indeed, the district court, although it struck down the redistricting plan, made a specific finding that the plaintiffs had not suffered any such harm. See Johnson v. Miller, 864 F. Supp. 1354, 1370 (S.D. Ga. 1994) (holding that the challenged redistricting plans caused the plaintiffs to suffer "no individual harm" and "had no adverse consequences for the[m]"), aff'd. 515 U.S. 900 (1995).

42. See Karlan, supra note 11, at 296 (noting that Miller "seems to have abandoned any requirement that the plaintiffs even allege, let alone prove," any of the special harms mentioned in Shaw I); see also Issacharoff \& Karlan, supra note 34, at 2285-86 n.48 (noting that in deciding Shaw claims on the merits, the Court has failed to require plaintiffs to prove that they have suffered any special stigmatic or representational harm).

43. See Issacharoff \& Goldstein, supra note 13, at 56; Karlan, supra note 11, at 296; Saunders, supra note 31 , at $325-26$.

44. See Bush v. Vera, 517 U.S. 952, 1045 (1996) (Souter, J., dissenting); Shanv II, 517 U.S. 899, 918 (1996) (Stevens, J., dissenting). In contrast to the Shaw I dissents, see 509 U.S. at 658-75 (White, J., dissenting); id. at 679-87 (Souter, J., dissenting), these dissents did not take the position that a showing of vote dilution or denial was necessary to make out an equal protection claim in this context. Instead, they seemed to acknowledge that a special disadvantage of some other kind, like stigmatic or representational harm. if adequately proven, might also suffice. See Shaw II, 517 U.S. at 926-29 (Stevens, J., dissenting); Vera, 517 U.S. at 1045-46 (Souter, J., dissenting). 
will presumably be received in equal measure by all state residents. For that reason, the claimed violation of a shared right to a colorblind districting process would not seem to implicate the Equal Protection Clause at all . . . ${ }^{45}$

Justice Souter's dissent in Bush v. Vera made essentially the same point. The equal protection claim recognized in Shaw, wrote Souter, is " at odds" with "the logic of traditional equal protection analysis," for it does not address "harm... to any identifiable class singled out for disadvantage." ${ }^{46}$ In Shaw and its progeny, he concluded, the Court has "broke[n] abruptly with . .. the very understanding of equal protection as a practical guarantee against harm to some class singled out for disparate treatment." 47

\section{SHAW AS DOCTRINAL EARTHQUAKE?}

Perhaps Justice Souter is right that the Court is dispensing with the notion-implicit in all of its prior equal protection cases, though seldom squarely stated - that a law cannot be challenged under the Equal Protection Clause unless it subjects an identifiable class of persons to some special disadvantage. Perhaps it is in fact effecting a significant change in its equal protection jurisprudence, declaring that the Equal Protection Clause forbids the state to use race in governing, absent truly extraordinary justification, even when it is not subjecting any identifiable class of persons to special disadvantage. ${ }^{48}$ There certainly are strong indications that at least three members of the Shaw majority-Justices Scalia, Kennedy, and Thomaswould like to see the Court's equal protection jurisprudence move in this direction, ${ }^{49}$ and it may well be that they are using Shaw and its progeny as a vehicle for doing just that. ${ }^{50}$

45. Shaw II, 517 U.S. at 923-24 (Stevens, J., dissenting).

46. Vera, 517 U.S. at 1053-54 (Souter, J., dissenting).

47. Id at 1053 .

48. For this interpretation of the cases, see James F. Blumstein, Shaw v. Reno and Miller v. Johnson: Where We Are and Where We Are Headed, 26 CuMB. L. REv. 503, 504 (1996). For an argument that such an interpretation of the Equal Protection Clause would be profoundly inconsistent with the original understanding, see Saunders, supra note 31.

49. See, e.g., Adarand Constructors v. Peña, 515 U.S. 200, 239 (1995) (Scalia, J., concurring in part and concurring in the judgment) (noting that the Constitution "reject[s] ... dispositions based on race"); id. at 240 (Thomas, J., concurring in part and concurring in the judgment) (observing that "under our Constitution, the government may not make distinctions on the basts of race"); Missouri v. Jenkins, 515 U.S. 70, 120-21 (1995) (Thomas, J., concurring) (asserting that "the principle that the government must treat citizens as individuals, and not as members of racial...groups," lies "[a]t the heart... of the Equal Protection Clause"); Johnson v. De Grandy, 512 U.S. 997, 1029-30 (1994) (Kennedy, J., concurring in part and concurring in the judgment) (commenting that "racial classifications do not become legitimate on the assumption that all persons suffer them in equal degree" (quoting Powers v. Ohio, 499 U.S. 400, 410 (1991))); City of Richmond v. J.A. Croson Co., 488 U.S. 469, 518 (1989) (Kennedy. J.. 
Whatever the merits of this theory as an explanation for the votes that Justices Scalia, Kennedy, and Thomas have cast in these cases, it cannot satisfactorily explain the Shaw doctrine itself as it is currently formulated. It cannot explain, for example, why the Court has held that the strict scrutiny of Shaw does not apply whenever the state intentionally takes race into account in districting, but only when it makes race the "predominant factor" in districting. ${ }^{51}$ If Shaw really means that all intentional uses of race by the state are unconstitutional, at least in the absence of truly compelling justification, then its strict scrutiny logically should apply whenever there is evidence that the state has intentionally considered race in districting, whether or not it has made race the "predominant factor" in that process. . $^{\text {" }}$

Nor can it explain why the Court, through Justice O'Connor, has insisted that the strict scrutiny of Shaw does not apply whenever the state intentionally designs a district to give a certain racial group a majority, so long as it does not substantially disregard certain "traditional" districting principles to do so..$^{53}$ Again, if Shaw really means that all intentional uses of

concurring in part and concurring in the judgment) (asserting that "racial neutrality is the driving force of the Equal Protection Clause"); id. at 521 (Scalia, J., concurring in the judgment) (characterizing the Fourteenth Amendment as embodying a general principle of colorblindness).

At the moment, these Justices concede-somewhat reluctantly-that there are some circumstances in which the use of race may be constitutionally permissible, though they maintain that these circumstances are few and far between. See, e.g., Croson, 488 U.S. at 519 (Kennedy. J., concurring in part and concurring in the judgment); id. at 520-21 (Scalia, J., concurring in the judgment).

50. For an argument that these three Justices are using the racial-gerrymandering cases as a vehicle for advancing their broader agenda of cradicating all use of race from govemmental decisionmaking, see Issacharoff \& Goldstein, supra note 13. at 48-49. Some observers place Chief Justice Rehnquist in the same camp. See id. In my view, however, his position on this matter is more àmbiguous. Unlike Justices Scalia, Kennedy, and Thomas, he joined Justice Souter's opinion for the Court in Lawyer v. Department of Justice, 521 U.S. 567 (1997), which upheld a race-conscious districting plan against equal protection challenge. He also joined Justice O'Connor's plurality opinion in Bush v. Vera, 517 U.S. 952 (1996), which indicated a greater tolerance for the use of race in redistricting than did the scparatc concurrences of Justices Kennedy and Thomas. Finally, he joined Part IV of Justice White's plurality opinion in United Jewish Organizations v. Carey, 430 U.S. 144 (1977), which rejected an equal protection challenge to a race-conscious districting plan.

51. See Vera, 517 U.S. at 958-59, 962-63 (plurality opinion): id. at 993 (O'Connor. J., concurring); Miller v. Johnson, 515 U.S. 900, 916-17 (1995); id. at 928-29 (O'Connor, J., concurring).

52. See Samuel Issacharoff, The Constitutional Contours of Race and Politics, 1995 SUP. CT. REV. $45,63,65$ (arguing that if Shaw means that "all . . . race-based decision making" by a state is "unconstitutional absent truly extraordinary, compelling state interests." then "any redistricting activity in which race played a role" should be suspect). Perhaps not surprisingly, Justices Scalia. Thomas, and Kennedy recently have begun to express some discomfor with this aspect of the doctrine. See infra note 137.

53. See Vera, 517 U.S. at 958-59 (plurality opinion) (asserting that the strict scrutiny of Shaw applies only where "the State has relied on race in substantial disregard of customary and traditional districting practices" (quoting Miller, 515 U.S. at 928 (O'Connor, J., concuming))); id. at 962 (holding that a showing that the state has "neglected traditional districting criteria" is "necessary" to trigger the strict scrutiny of Shaw'); id. at 993 (O' Connor, J., concuming) (finding that the strict scrutiny of Shaw applies "[o]nly if traditional districting criteria are neglected and that neglect is predominantly due to the misuse of race"); id. at 1012 (Stevens, J., dissenting) 
race by the state are unconstitutional, absent truly compelling justification, then its strict scrutiny logically should apply whenever there is evidence that the state has intentionally designed a district to have a certain racial makeup, whether or not it has substantially disregarded any traditional districting principles in the process. ${ }^{54}$

Nor, finally, can it explain the peculiar standing rule that the Court, again through Justice O'Connor, has crafted for Shaw claims. Under that rule, a Shaw challenge to a state's use of race in constructing a statewide districting plan is not available to every individual who resides in the state. ${ }^{55}$ Instead, only those individuals who reside in districts that have been "racially gerrymandered" - that is, districts whose lines have been drawn "predominantly" on the basis of race, in substantial disregard of certain traditional districting principles-have standing to assert such a claim. ${ }^{36}$ If Shaw really means that it is unconstitutional for the state to take an individual's race into account in dealing with him, at least in the absence of a truly compelling justification, then this rule makes no sense. To construct one or more "racially gerrymandered" districts, a state must take race into account, at least to some degree, in designing the other districts in the same plan. ${ }^{57}$ If mere consideration of race is the problem, then all of the state's residents should have standing to assert a Shaw claim. ${ }^{58}$

To be sure, all of these quirks are clearly contributions of Justice O'Connor, who is less hostile to governmental use of race than are Justices Scalia, Thomas, and Kennedy. But Justice O'Connor is the principal

(same); id. at 1056-57, 1065, 1072-73 (Souter, J., dissenting) (same); see also DeWitt v. Wilson. 856 F. Supp. 1409 (E.D. Cal. 1994) (refusing to apply the strict scrutiny of Shaw to an intentionally created majority-minority district that complied with traditional notions of compactness), aff'd mem., 515 U.S. 1170 (1995).

54. See Richard Briffault, Race and Representation After Miller v. Johnson, $1995 \mathrm{U}$. CHI. LEGAL F. 23, 45 (arguing that "[i]f the value vindicated by Shaw is racial neutrality, then it is difficult to see why ... the concern ... should be cabined to irregularly shaped districts and not expanded to ... any intentional use of race in districting"). Perhaps not surprisingly, Justices Scalia and Thomas have voiced explicit disagreement with this aspect of the doctrine, see Vera, 517 U.S. at 1000-03 (Thomas, J., concurring in the judgment) (arguing that the strict scrutiny of Shaw should apply whenever the state "affirmatively undertakes to create" a district of a certain racial makeup, whether or not it disregards any traditional districting principles in order to do so), and Justice Kennedy has evidenced considerable discomfort with it, see id. at 996 (Kennedy, J., concurring) (explicitly reserving judgment on this question).

55. See United States v. Hays, 515 U.S. 737, 744 (1995).

56. See id. at 744-45.

57. See Issacharoff \& Goldstein, supra note 13, at 64 ("[1]n districting, a decision to include one kind of person is fundamentally also a decision to exclude other kinds of people."); Issacharoff \& Karlan, supra note 34 , at $2286-87$ (explaining that both the minority citizens who were included in the district and the white citizens who were excluded from it were "victims of the same offensive, demeaning, or reductionist assumptions" about their political identity (emphasis omitted)).

58. See Issacharoff \& Goldstein, supra note 13, at 63-64; Issacharoff \& Karlan, supra note 34 , at $2285-88$. 
architect of the Shaw doctrine, ${ }^{59}$ and these quirks are part of the fabric of the doctrine as it now stands. As a result, no theory that purports to explain what the Court as an institution is doing in these cases is worth its salt unless it can account for them. Since the theory described above cannot, it is not a plausible explanation for what the Court as a whole is doing here. If we are to understand the Shaw doctrine, then, we must find something else.

One possibility, the one I want to explore here, is that Shaw and its progeny do not alter the traditional notion that proof of special disadvantage to an identifiable class of persons is an essential element of an equal protection claim, but instead establish a presumption that plaintiffs in raceconscious districting cases can use to prove it. ${ }^{60}$ Presumptions are a familiar feature of the Court's equal protection jurisprudence; indeed, the multitiered standard of review is in reality but a series of presumptions. ${ }^{61}$ And we know from Brown v. Board of Education ${ }^{62}$ that when a state deliberately cordons off a racial minority from the rest of the population in its schools or other public facilities, it is conclusively presumed to be subjecting that minority to the special disadvantage of social stigmatization. ${ }^{63}$ Perhaps Shaw and its progeny rest on a similar presumption. If so, then the Court's work here may not be as radical as it first appears, even if we grant Shaw's critics their basic premise-that a law must subject an identifiable class of persons to some special disadvantage in order to be vulnerable to challenge under the Equal Protection Clause.

In the next Part, I develop this alternative understanding of the cases.

59. In addition to the opinion for the Court in the inaugural case of Shaw l, 509 U.S. 630 (1993), Justice O'Connor wrote the Court's opinion in Hay's, 515 U.S. 737, which announced the curious standing rule that applies to Shaw claims; a concurrence in Miller v. Johnson. S15 U.S. 900, 928 (1995), which added an important qualification to Justice Kennedy's majority opinion; the plurality opinion in Vera, 517 U.S. at 952; and a separate concurrence in the same case, see id. at 990-95. As Sam Issacharoff has said, "There is no escaping the fact that the Supreme Court's equal protection law is being driven by Justice O'Connor." Issacharoff, supra note 52, al 63.

60. Both Justice Souter and Justice Stevens have alluded to this possibility in dissent, though they have asserted that there is no basis for presuming discriminatory effect here. See Shav 11,517 U.S. 899, 928-29 (1996) (Stevens, J., dissenting); Shaw I, 509 U.S. at 687 n.9 (Souter, J., dissenting).

61. See Saunders, supra note 31 , at $307-08$ \& n.286.

62. 347 U.S. 483 (1954).

63. This is, in any event, the conventional academic explanation for Brown. See, e.g., LAURENCE H. TRIBE, AMERICAN CONSTITUTIONAL LAW $\$ 16-15$, al 1477-78 (2d ed. 1988); Charles L. Black, Jr., The Lawfulness of the Segregation Decisions, 69 YALE LJ. 421, 429-30 \& n.25 (1960); Paul Brest, The Supreme Coun, 1975 Term-Foreword: In Defense of the Antidiscrimination Principle, 90 HARV. L. REV. 1, 9-10 (1976). For a different explanation, see Missouri v. Jenkins, 515 U.S. 70 (1995) (Thomas, J., concurring), which asserts that "[s]egregation was not unconstitutional because it...caused psychological feelings of inferiority," but because it involved the "classifi[cation] [of] students based on their race." Id. at 121-23. 


\section{AN ALTERNATIVE UNDERSTANDING OF SHAW: THE MIRANDA OF RACE-CONSCIOUS DISTRICTING}

From the beginning, the Court, through Justice O'Connor, has insisted that Shaw claims are concerned with individualized harm to a class of persons who are being singled out for special disadvantage. ${ }^{64}$ To date, however, the Court has been unable to explain precisely how this can be so, given its failure to require plaintiffs asserting these claims to prove that the laws they challenge actually subject them-or anyone else-to a special disadvantage. The explanation, I suggest, is that the Court has substituted a conclusive presumption, or per se rule, for case-by-case determination of this element of the equal protection claim. In this respect, the Court's work closely resembles what it did in Miranda v. Arizona. ${ }^{65}$

In Miranda, a five-to-four majority of the Court relied upon the Fifth Amendment privilege against self-incrimination to impose limits on police interrogation of suspects in custody. The decision established strict "warning" and "waiver" requirements with which law-enforcement officials at all levels of government were required to comply if they wished to avoid having the confessions they obtained excluded from criminal trials. ${ }^{66}$ The Court's decision ignited a firestorm of controversy. The criticisms leveled at it were much like those that have been leveled at Shaw: that these new limits on custodial interrogation had no foundation in the Fifth Amendment and that the Court was improperly invoking the Constitution to justify imposing its own policy preferences upon the nation. ${ }^{67}$

The Miranda majority offered the following justification for its decision to impose these limits on police behavior:

(1) The Fifth Amendment privilege against self-incrimination is one of our most important constitutional rights. ${ }^{68}$

64. See Shaw I, 509 U.S. at 649-50; accord United States v. Hays, 515 U.S. 737,744 (1995).

65. 384 U.S. 436 (1966).

66. See id. at $441-91$.

67. For some prominent examples of such criticisms, see Miranda, 384 U.S. at 504-14 (Harlan, J., dissenting); and U.S. DEP'T OF JUSTICE, OFFICE OF LEGAL POLICY, REPORT TO THE ATTORNEY GENERAL ON THE LAW OF PRE-TRIAL INTERROGATION 3-41 (Feb. 12, 1986, with addendum of Jan. 20, 1987), reprinted in 22 U. MICH. J.L. REFORM 437, 453-90 (1989). Even today, some 30 years after it was decided, Miranda remains the subject of controversy. See, e.g. United States v. Dickerson, 166 F.3d 667 (4th Cir.), cert. granted, 120 S. Ct. 578 (1999); Paul G. Cassell, All Benefits, No Costs: The Grand Illusion of Miranda's Defenders, 90 Nw. U. L. REv. 1084 (1996); Paul G. Cassell, Miranda's Social Costs: An Empirical Reassessment, 90 Nw. U. L. REv. 387 (1996); Paul G. Cassell \& Richard Fowles, Handcuffing the Cops? A Thirty-Year Perspective on Miranda's Harmful Effects on Law Enforcement, 50 STAN. L. REV. 1055 (1998).

68. See Miranda, 384 U.S. at $457-58$ (describing the privilege against self-incrimination as "one of our Nation's most cherished principles"). 
(2) Custodial interrogation, as it is currently being practiced in this country, often results in suspects' being "compelled" to incriminate themselves, in violation of that right. ${ }^{69}$

(3) The Court cannot read the Fifth Amendment to outlaw all custodial interrogation or to forbid all uses of confessions in criminal trials. ${ }^{70}$

(4) But the Court can, pursuant to its authority to enforce the Constitution, require those who conduct custodial interrogations to take certain precautions to reduce the risk that they will "compel" suspects to incriminate themselves within the meaning of the Fifth Amendment."

(5) The precautions the Court recommends are to administer certain specific warnings before beginning interrogation and to cease interrogation unless the suspect makes a clear and unequivocal waiver of his right to remain silent. ${ }^{72}$

(6) The Court cannot say that the Constitution necessarily requires the police to take these particular precautions, only that it requires them to take precautions that are at least as effective as these. ${ }^{23}$

(7) To encourage the police to do that, the Court will direct the lower courts not to admit into evidence any statement made in a custodial interrogation that was not conducted in compliance with either its recommended precautions or other precautions that the Cour deems equally effective. ${ }^{74}$

(8) Requiring the police to take these precautions when they conduct custodial interrogations should not interfere unduly with their ability to enforce the criminal law, for the FBI has compiled an excellent record of law enforcement while taking similar precautions. ${ }^{75}$

In later cases, the Court described Miranda's exclusionary rule as resting on an irrebuttable presumption, or per se rule, that any statement made by a suspect during a custodial interrogation that had not been conducted in compliance with the Court's recommended safeguards had been "compelled" within the meaning of the Fifth Amendment." The Court acknowledged that this rule was overbroad-that it required courts to exclude some statements that had not been "compelled" in the constitutional sense. ${ }^{n}$ But the Court found use of the per se rule to be

69. See id. at $445-58,467$.

70. See id at 478 .

71. See id. at $439,444,467,490-91$.

72. See id. at $467-76$.

73. See id. at 467,490 .

74. See id. at $444,476,478-79$.

75. See id. at $479-86$.

76. See Oregon v. Elstad, 470 U.S. 298, 306-07 \& n.l (1985); New York v. Quarles, 467 U.S. 649,654 (1984); id. at 662 (O'Connor, J., concurring in part and dissenting in parn).

77. See Elstad, 470 U.S. at 306-10; Quarles, 467 U.S. at 654-55 \& n.5; Michigan v. Tucker, 417 U.S. $433,442-46$ (1974). 
justifiable notwithstanding its overbreadth, because it avoided various problems associated with case-by-case assessment of the compulsion issue ${ }^{78}$ and encouraged the police to modify their behavior in a way that would substantially reduce the number of constitutional violations that occurred during custodial interrogation. ${ }^{79}$

The limits on race-conscious districting set forth in Shaw and its progeny can, I suggest, be justified on similar grounds. ${ }^{80}$ The argument would go something like this: Race-conscious districting, at least as it has been practiced since the 1990 census, poses the same sort of risk to individual equal protection rights that custodial interrogation, as it was being conducted in the early 1960s, posed to individual Fifth Amendment rights. The Court cannot read the Equal Protection Clause to outlaw all consideration of race in districting. ${ }^{81}$ But it can, pursuant to its authority to enforce the Constitution, require those who engage in race-conscious districting to take certain precautions to reduce the risk that they will violate individual equal protection rights. The precaution the Court recommends is to adhere to certain traditional districting principles in designing the districts. The Court is unwilling to say that the Constitution necessarily requires state actors engaged in race-conscious districting to take this particular $_{\text {precaution }}{ }^{82}$-just that it requires them to take some precaution that is at least as effective as this one. To encourage them to do that, the Court will direct the lower courts to apply a per se rule that whenever the state takes race into account in designing an electoral district, without taking either this recommended precaution or some equally effective alternative, it presumptively subjects the district's residents to the sort of

78. See Berkemer v. McCarty, 468 U.S. 420, 433 \& n.20 (1984).

79. See Miranda, 384 U.S. at $444,467,476,478-79$.

80. There is, of course, one rather obvious distinction between what the Court has done here and what it did in Miranda. In Miranda, the Court "acted in the absence of a relevant Act of Congress." United States v. Dickerson, 166 F.3d 667, 691 (4th Cir.), cert. granted, 120 S. Ct. 578 (1999). Here, by contrast, it has acted in the face of the Voting Rights Act of 1965, 42 U.S.C. $\S 1973$ (1994). However, this may be a distinction without a difference. While the Voting Rights Act is designed to enforce Fourteenth and Fifteenth Amendment rights, it does not purport to remedy or prevent the particular kind of equal protection violation with which the Court is here concerned: the passage of race-conscious districting laws that have the effect of singling out certain individuals, without adequate justification, for special stigmatic and representational harms. In this respect, the situation that the Court confronted when it handed down Shaw and its progeny was in fact much like the one that it confronted when it handed down Miranda: Congress had failed to take action to deal with the particular constitutional evil about which the Court was concerned.

81. See Bush v. Vera, 517 U.S. 952, 995 (1996) (O'Connor, J., concurring) (noting that "race-based action" sometimes is necessary to "remedy the reality of racial inequality in our political system"); Shaw I, 509 U.S. 630, 642 (1993) (asserting that "race-conscious redistricting is not always unconstitutional").

82. See Vera, 517 U.S. at 962 (plurality opinion) (maintaining that "[t]he Constitution does not mandate regularity of district shape"); Shaw l, 509 U.S. at 647 (observing that compliance with traditional districting criteria like "compactness, contiguity, and respect for political subdivisions" is "not . . . constitutionally required"). 
special disadvantage that will support an equal protection claim. Application of this per se rule should not interfere unduly with states' ability to design workable electoral districts, for virtually every state in the country adhered to these districting principles until the $1990 \mathrm{~s}^{83}$ when the United States Department of Justice began to pressure some of them to draw bizarrely shaped districts in order to maximize representation of African Americans in the nation's legislatures. ${ }^{84}$

Of course, if the Court is engaging in this sort of reasoning here, it is not doing so explicitly. The Court never has attempted to justify the Shaw doctrine in precisely this way. But this is not unusual-the prophylactic justification for a rule often fails to emerge until well after the rule itself is promulgated. ${ }^{85}$ And as David Strauss has pointed out, whether a doctrine can be considered prophylactic should depend not "on how the Court happens to have written its opinions but on how the relevant constitutional provision is most plausibly interpreted." ${ }^{86}$ That the Court itself has yet to provide a prophylactic justification for Shaw therefore should not prevent us from considering the very real possibility that the doctrine can be justified in just those terms. ${ }^{87}$ In this Part, I attempt to develop that justification.

83. See Vera, 517 U.S. at 985 (plurality opinion); Miller v. Johnson, 515 U.S. 900,928 (1995) (O'Connor, J., concurring) (asserting that Shaw and its progeny "do[ ] not throw into doubt the vast majority of the Nation's 435 congressional districts," because "the States have drawn the boundaries in accordance with . . . customary districting principles").

84. See Miller, 515 U.S. at $921,924-25$ \& n.* (discussing the Justice Department's “black max" policy).

85. For example, the prophylactic justification for Miranda's exclusionary rule did not emerge fully until Michigan v. Tucker, 417 U.S. 433 (1974); New York v. Quarles, 467 U.S. 649 (1984); and Oregon v. Elstad, 470 U.S. 298 (1985). Similarly, the prophylnetic justification for the rule of North Carolina v. Pearce. 395 U.S. 711 (1969). which held that whenever a judge imposes a more severe sentence upon a criminal defendant following retrial, it will be treated as the product of unconstitutional vindictiveness unless the judge justifies the increase on the record by reference to the defendant's conduct after the original sentencing, see id. at 726 , did not emerge until Colten v. Kentucky, 407 U.S. 104 (1972); Chaffin v. Stynchcombe, 412 U.S. 17 (1973); and Michigan v. Payne, 412 U.S. 47 (1973).

86. Strauss, supra note 20, at 196; see also Joseph D. Grano, Miranda's Consritutional Difficulties: A Reply to Professor Schulhofer, 55 U. CHI. L. REV. 174, 181 (1988).

87. In this regard, it is worth noting that Justice $0^{\prime}$ Connor has been the principal arehitect of the Shaw doctrine, see supra note 59, and that minimalism has always been one of the most striking characteristics of her constitutional jurisprudence, see, e.g., Jeffrey Rosen. Foreword, 97 MICH. L. REV. 1323, 1331 (1999) (citing Justice O'Connor's opinions in Shany and its progeny as prime examples); Jeffrey Rosen, The Age of Mixed Results. NEW REPUBLIC, June 28, 1999, at 43. 46 (reviewing CASS R. SUNSTEIn, ONE CASE AT A TIME: JUdiclal Minialalasal IN the SUPREMe COURT (1999)). For a general account of the Rehnquist Court's penchant for minimalism, see SUNSTEN, supra; and Cass R. Sunstein, The Supreme Court, 1995 Term-Foreword: Leaving Things Undecided, 110 HARV. L. REV. 4 (1996). 


\section{A. The Nature of the Constitutional Violation Feared}

To understand the prophylactic justification for Shaw, we must first understand the premise with which the Court begins: that race-conscious districting, as it has been practiced in this country since the 1990 census, poses a serious risk to individual equal protection rights. This is so, the Court insists, even when it does not have the effect of diluting the strength of any identifiable group's vote. ${ }^{88}$ Why? The Court's general answer is that it "threatens" to subject certain individuals to special disadvantages of a different sort, disadvantages that, if not adequately justified, will violate their equal protection rights. ${ }^{89}$ The Court has indicated that these special disadvantages are of two basic types: "stigmatic" harms and "representational" harms. ${ }^{90}$ It has done little, however, to describe these harms or to explain how race-conscious districting may inflict them. The Court's failure to provide these details has, I believe, tended to obscure the Miranda-like reasoning that lies behind the Shaw doctrine. I therefore begin by attempting to describe, in some detail, the special stigmatic and representational harms with which the Court seems to be concerned.

\section{Stigmatic Harm}

The precise nature of the stigmatic harm with which the Court is concerned is somewhat elusive. The Court's rhetoric about "segregation" and "apartheid," 91 taken literally, would suggest that it is the same sort of stigmatic harm that was involved in Brown and the other segregation cases: a feeling of inferiority generated by the state's broadcasting of the message that "you are a pariah, not fit to mix with the rest of society." 92 But this cannot be what the Court means. As Shaw's critics have often pointed out, it is impossible to say with a straight face that the plaintiffs in Shaw and its progeny-all of whom resided in districts that were quite racially integrated - were being stigmatized in that particular way. ${ }^{93}$

88. See Shaw I, 509 U.S. 630, 649-50 (1993).

89. See id. (asserting that race-conscious districting "threatens special harms that are not present in our vote-dilution cases"); see also United States v. Hays, 515 U.S. 737, 744-45 (1995) (discussing the special harms caused by racial voting classifications).

90. See Hays, 515 U.S. at 744-45.

91. See, e.g., Shaw I, 509 U.S. at 642 (characterizing the plaintiffs' claim as an allegation that the state had "segregate[d] the races for purposes of voting"); id. at 647 (asserting that the raceconscious districting plan under review "bears an uncomfortable resemblance to political apartheid").

92. Cf. Daniel Farber \& Suzanna Sherry, The Pariah Principle, 13 Const. Commentary 257 (1996) (arguing that the principle that the government may not designate any group as social "pariahs" is a fundamental, though often incompletely articulated, aspect of the Court's equal protection jurisprudence).

93. See, e.g., Bush v. Vera, 517 U.S. 952, 1055 (1996) (Souter, J., dissenting); Shaw II, 517 U.S. 899, 928 (1996) (Stevens, J., dissenting); Miller v. Johnson, 515 U.S. 900, 931 (1995) 
Nor can the stigmatic harm here be an insult to individual dignity flowing from the state's use of race to predict political identity, as the Court's references to "racial stereotyping" ${ }^{94}$ might lead the casual reader to think. If it were, the Court would have no principled reason to limit the class of persons who have standing to assert the claim to those who reside within a district, the design of which reflects the subordination of its traditional districting principles to race, ${ }^{95}$ for whenever a state draws a district like that, it necessarily is assigning voters on both sides of the district's lines--both those it includes in the district and those it excludes from it-by race. ${ }^{96}$

Properly understood, the stigmatic harm with which the Court is concerned is, I believe, the insult that may be suffered when one is placed in a district that everyone knows has been created for the special benefit of one racial group. The precise nature of the potential insult varies, depending on the race of the individual. For members of the race for whose special benefit the district is being created, it is the implication that they need

(Stevens, J., dissenting); Shaw l. 509 U.S. at $671 \mathrm{n.7}$ (White. J., dissenting): id. at $686 \mathrm{n.9}$ (Souter, J., dissenting). This is not to say that an electoral districting plan thit assigned all members of a given racial minority to a single district consisting entirely of members of that minority could not subject that minority to the very kind of stigmatic harm with which the Brown Court was concerned. But none of the districts the Coun struck down under Shan' came close to doing that: to the contrary, they were all quite racially mixed. See T. Alexander Alcinikoff \& Samuel Issacharoff, Race and Redistricting: Drawing Constitutional Lines Affer Shaw v. Reno, 92 MICH. L. REV. 588, 611-12 (1993) (observing that the districts challenged in Shaw $I$ were "remarkably integrated by usual American standards"); Pamela S. Karlan. Our Separatism? Voting Rights as an American Nationalities Policy, 1995 U. CHI. LEGAL F. 83, 94 \& nn.52-53 (noting that the districts challenged in Shaw I were "among the most integrated districts in the country"): Saunders, supra note 31 , at 319 n.327 (noting that the districts challenged in Shav / were each approximately $53 \%$ black and $45 \%$ white). For further criticism of the Court's use of the terms "segregation" and "apartheid" in this context, see Vera. 517 U.S. at 1055 (Souter, J., dissenting), in which Justice Souter points out that " [ $w$ ]hatever [the district challenged in Shaw I] may have symbolized, it was not "apartheid""; and Shaw l. 509 U.S. at 67! n.7 (Whitc. J.. dissenting), in which Justice White observes that the term "segregatlion]" is not "a particularly accurate description of what has occurred" here.

94. See, e.g., Shaw I, 509 U.S. at 647 (describing the assumption that "members of the same racial group-regardless of their age, education, economic status, or the community in which they live-think alike, share the same political interests, and will prefer the same candidates at the polls" as an "impermissible racial stereotype[ ]"); id. at 650 (criticizing racial gerrymandering for reinforcing racial stereotypes).

95. See Hays, 515 U.S. at 744-45 (explaining the Court's standing doctrine as limited to those who live in a gerrymandered district).

96. See Issacharoff \& Goldstein, supra note 13, at 64 (explaining that * in districting, a decision to include one kind of person is fundamentally also a decision to exclude other kinds of people"); Issacharoff \& Karlan, supra note 34, at 2286-87 (arguing that both the minority citizens who were included in the district and the white citizens who were excluded from it were "victims of the same offensive, demeaning, or reductionist assumptions" about their political identity (emphasis omitted)). Of course, it is possible that the Hays standing rulc has no principled basis. but is simply a crude way of limiting the number of Shaw claims that can be brought. If so, it is a rather ineffective means of accomplishing that purpose. See Issacharoff, supra note 52, at 62 (noting that plaintiffs who satisfy the Hays standing rule will always be "readily available and readily recruitable" in these cases); Issacharoff \& Goldstein, supra note 13, at 62 (same). 
special help to win elections. ${ }^{97}$ For everyone else in the district-the "filler people" of other races, added to bring the district into compliance with the mandate of one person, one vote ${ }^{98}$-it is the implication that those responsible for drawing districts do not care about their political interests, whatever they are. ${ }^{99}$

Like all stigmatic harms, these are "expressive harms," for they "result[] from the ideas or attitudes expressed through a governmental action, rather than from the more tangible or material consequences the action brings about." ${ }^{100}$ But they are not harms that all persons who live in a state that has used race in districting can legitimately claim to have suffered, as Shaw's critics have suggested ${ }^{101}$ Instead, they are suffered, if at all, by only a small subset of the state's population: those who reside in districts that everyone knows have been created for the special benefit of a single racial group. ${ }^{102}$

97. The notion that racial preferences may inflict this sor of stigmatic harm upon their intended beneficiaries is a familiar one. See, e.g., Adarand Constructors v. Peña, 515 U.S. 200. 241 (1995) (Thomas, J., concurring in part and concurring in the judgment) (asserting that racial preferences "stamp minorities with a badge of inferiority" and reinforce the belief that "because of chronic and apparently immutable handicaps, minorities cannot compete with [the majority] without [its] patronizing indulgence"); City of Richmond v. J.A. Croson Co., 488 U.S. 469, 51617 (1989) (plurality opinion) (stating that racial preferences stigmatize their intended beneficiaries); Fullilove v. Klutznick, 448 U.S. 448, 545 (1980) (Stevens, J., dissenting) (explaining that racial preferences are "perceived by many as resting on an assumption that those who are granted this special preference are less qualified in some respect that is identified purely by their race"); United Jewish Orgs. v. Carey, 430 U.S. 144, 173-74 (1977) (Brennan, J.. concurring in part) (asserting that racial preferences "may act to stigmatize [the] recipient groups," by "imply[ing] to some the recipients' inferiority and especial need for protection"). But see Vera, 517 U.S. at 1055 (Souter, J., dissenting) (stating that the state's decision to draw a district in which a given racial minority has a majority "implies nothing about the capacity ... of the minority to which it gives the chance of electoral success").

98. See Aleinikoff \& Issacharoff, supra note 93 , at 630-33 (coining the term "filler people").

99. Cf. id. at 633 ("Whenever districts are drawn to create a designated group beneficiary, the nonpreferred group is essentialized or, worse, denied their dignitary right[s] . . by having their welfare discounted."). But see Miller v. Johnson, 515 U.S. 900, 931 n.1 (1995) (Stevens, J., dissenting) (asserting that white voters are not stigmatized by their assignment to majorityminority districts).

100. Richard H. Pildes \& Richard G. Niemi, Expressive Harms, "Bizarre Districts," and Voting Rights: Evaluating Election-District Appearances After Shaw v. Reno, 92 MICH. L. REv. 483, $506-07$ (1993) (coining the term "expressive harm"); see also Vera, 517 U.S. at 984 (plurality opinion) (referring to "the expressive harms with which we are dealing"); id. at 1053 (Souter, J., dissenting) (asserting that the harm involved here is "probably best understood as an "expressive harm"' (quoting Pildes \& Niemi, supra, at 506-07)).

101. See Vera, 517 U.S. at 1053 (Souter, J., dissenting) (commenting that the "expressive harms" the Court is describing "would seem to play no favorites, but to fall on every citizen ... alike"); Shaw II, 517 U.S. 899, 923-24 (1996) (Stevens, J., dissenting) (noting that "[t]he supposedly insidious messages that Shaw I contends will follow from extremely irregular racebased districting will presumably be received in equal measure by all state residents"); id. at 928 (same); Issacharoff \& Karlan, supra note 34, at 2286 (asserting that the expressive harms the Court is describing are suffered by "all voters" in the state); Pildes, supra note 18, at 2539 n.122 (same); Pildes \& Niemi, supra note 100, at 514 (observing that any voter in the state can "legitimately claim" to have suffered the "expressive harms" the Court is describing).

102. Of course, if all the electoral districts in a state fit this bill, then any resident of that state might legitimately claim to have suffered such stigmatic harm. The Court ignores this difficulty. 


\section{Representational Harm}

The precise nature of the representational harm with which the Court seems to be concerned is even more elusive. Again, the Court's rhetoric is somewhat misleading. Taken literally, it suggests harm to the quality of representation caused by the fact of representation by someone of a different race. ${ }^{103}$ But surely this is not what the Court means, for such a notion of representational harm would depend on the very stereotypical assumptions that it finds so offensive: that members of different races necessarily have different political interests, and that it is impossible for an elected official of one race to provide citizens of another with effective representation. ${ }^{104}$

Properly understood, the representational harm that the Court is invoking has nothing to do with the race of the plaintiff or his representative. ${ }^{105}$ Rather, it has to do with the fact that his district's population has been chosen on the basis of race. This gives rise to two closely related risks. The first is that the district's representatives, whatever their own race, will "believe that their primary obligation is to represent only the members of [the racial] group [that has a majority in the district], rather than their constituency as a whole." ${ }^{106}$ If so, then residents of the district who are not members of that racial group-the "filler people"may receive representation of a lesser quality than that received by its other residents. ${ }^{107}$

The second risk is that the district will be an irrational district-so irrational that no one can possibly represent it effectively. If we assume, as

apparently because it assumes that such a situation never will arise. Cf. Miller, 515 U.S. at 928-29 (O'Connor, J., concurring) (asserting that the Shaw doctrine "does not throw into [constitutional] doubt the vast majority of the Nation's 435 congressional districts. . . . even though race may well have been considered" in their design).

103. See Shaw I, 509 U.S. 630, 648 (1993) ("When a district obviously is created solely to effectuate the perceived common interests of one racial group, elected officials are more likely to believe that their primary obligation is to represent only the members of that group, rather than their constituency as a whole."). For an example of someone who has been misled by this rhetoric, see John Hart Ely, Standing To Challenge Pro-Minorin Gernymanders, 111 HARV. L. REv. 576, 587 (1997), in which Professor Ely characterizes the individualized harm with which the Court is concerned as the inability to elect someone of one's own race.

104. Shaw's critics have delighted in pointing out this problem. See, e.g., Shan II, 517 U.S. at 927-28 (Stevens, J., dissenting); Miller, 515 U.S. at 930 (Stevens, J., dissenting); Issacharoff \& Goldstein, supra note 13, at 55 \& nn.36-38; Issacharoff \& Karlan, supra note 34, at 2278-79. 2287, 2290-91; Karlan, supra note 11, at 293-96.

105. See Shaw I, 509 U.S. at 638 (noting that the plaintiffs' complaint did not identify their race).

106. Id. at 648 .

107. Perhaps this is what Professor Ely really means when he says that "a filler person ends up to some degree worse off than someone who is a member of the racial majority of the district in which he lives." Ely, supra note 103, at 590. 
the Court does, that race is not an accurate predictor of political interest, ${ }^{108}$ then a district constructed on the basis of race, whatever its precise racial makeup, is functionally equivalent to a district constructed by drawing names at random from a hat. There is a substantial risk that its residents will have next to nothing in common with one another politically. If that is so, then all of them-black, white, purple, and green-may end up receiving representation of a lesser quality than that received by persons who live in districts that have been designed on more rational grounds. ${ }^{109}$

Unlike the stigmatic harms that are said to accompany them, these representational harms are not "expressive" harms. But neither are they harms that anyone who lives in a state that has used race in districting can legitimately claim to have suffered. Instead, they are suffered, if at all, only by those who reside in districts whose representatives believe that their primary obligation is to represent only the members of a given racial group and whose residents have little in common with one another politically. ${ }^{10}$

This is, then, the nature of the constitutional violation with which the Court seems to be concerned in Shaw: the singling out of certain individuals for special stigmatic and representational harms, without adequate justification. The Court does not deny that race-conscious districting can also give rise to a different kind of violation of equal protection rights: the unjustified dilution of the strength of certain persons' voting strength. "' But it regards that risk as adequately constrained by pre-Shaw doctrine.

\section{B. The Precautionary Measure: Compliance with Traditional Districting Principles}

To understand the prophylactic justification for Shaw, we must also understand the Court's second premise: that race-conscious districting is less likely to violate individual equal protection rights when the districts it

108. See Shaw I, 509 U.S. at 647 (criticizing the assumption "that members of the same racial group-regardless of their age, education, economic status, or the community in which they live-think alike, share the same political interests, and will prefer the same candidates at the polls"). Of course, as Shaw's critics have pointed out, the existing empirical evidence tends to suggest that there may in fact be a substantial correlation between an individual's race and his or her political interests and preferences, at least for the moment. For extensive documentation of this correlation, see DONALD R. KINDER \& LYNN M. SANDERS, DIVIDED BY COLOR: RACIAL POLITICS AND DEMOCRATIC IDEALS (1996); and LUBLIN, supra note 12. But that is itrelevant to my project here, which is to explain why the Court seems to think that drawing districts on the basis of race may cause some or all of the residents of those districts to suffer some sort of "representational harm."

109. See Prosser v. Elections Bd., 793 F. Supp. 859, 863 (W.D. Wis. 1992) (per curiam) ("To be an effective representative, a legislator must represent a district that has a reasonable homogeneity of needs and interests; otherwise, the policies he supports will not represent the preferences of most of his constituents.").

110. Again, the Court ignores the possibility that all of the electoral districts in the state might fit this bill.

111. See Shaw l, 509 U.S. at 640. 
produces comply with certain traditional districting principles such as compactness, contiguity, and respect for the integrity of political subdivisions. Why? Once again, the Court has told us the answer in very general terms: because it is less likely to subject anyone to special stigmatic and representational harms. ${ }^{112}$ But the Court again has failed to provide us with a critical detail: an explanation of why this might be so. The Court's failure to provide this detail has, I believe, tended to obscure further the Miranda-like reasoning that lies behind the Shaw doctrine. As before, however, it is possible to craft a plausible explanation for why raceconscious districting is less likely to inflict the special stigmatic and representational harms with which the Court is concerned when the districts it produces comply with traditional districting principles.

First of all, each district will be less likely to be perceived as having been created for the special benefit of one racial group. No matter what its racial makeup relative to the state's population as a whole, it will be fairly regular-looking, and the average person, who has no idea what information the state actually took into account in designing it, will be less likely to assume that it was created for the special benefit of a particular racial group. Its residents therefore will be less likely to feel stigmatized by their assignment to $\mathrm{it}^{113}$ its representatives less likely to assume that their primary obligation is to represent only the members of a particular racial group, ${ }^{114}$ and its "filler people" less likely to suffer the special representational harm that flows from being represented by someone who feels no obligation to consider their interests. ${ }^{135}$

In addition, each district will be less likely to be made up of persons who have no common political interests. No matter what its precise racial makeup, it will consist of individuals who live relatively close to one another and are likely, by virtue of their geographic proximity, to have some common political interests. ${ }^{116}$ Its residents therefore will be less likely to suffer the special representational harm that can flow from being placed in a district whose design is so irrational that no one can possibly represent its residents effectively. ${ }^{117}$

This is, I suggest, the explanation for the Court's assumption that raceconscious districting is less likely to violate individual equal protection rights when it produces districts that comply with the traditional districting

112. See United States v. Hays, 515 U.S. 737. 741-45 (1995).

113. See supra notes $91-102$ and accompanying text.

114. Cf. Shaw I, 509 U.S. at 648.

115. See supra notes $105-107$ and accompanying text.

116. Geographic proximity is thought to correlate with shared political interest. See, e.g., Prosser v. Elections Bd., 793 F. Supp. 859, 863 (W.D. Wis. 1992) (per curiam) (stating that "[t]here is some although of course not a complete correlation between geographical propinquity and community of interests").

117. See supra notes 108-109 and accompanying text. 
principles that the Court has identified. If the Court's assumption is correct, then those who engage in race-conscious districting can reduce significantly the constitutional risks associated with their behavior by taking a simple precautionary measure: making sure that the districts they produce comply with those traditional districting principles.

\section{The Per Se Rule and Its Justification}

To understand the prophylactic justification for Shaw, we must, finally, understand why it might make sense to substitute a per se rule on discriminatory effect for case-by-case assessment of that issue in this context. For it is a per se rule that the Court is adopting here: The Court is not saying that race-conscious districting that fails to comply with its traditional districting principles can, in some circumstances, have the effect of singling out certain individuals for special stigmatic and representational harms, but rather that it will be conclusively presumed to have such an effect in all cases. The rule is somewhat overbroad, for there will be cases in which some or all of the residents of a district the boundaries of which have been drawn predominantly on the basis of race, in substantial disregard of traditional districting principles, will not suffer any of the special stigmatic and representational harms to which the Court refers. ${ }^{118}$ As I explain below, however, there may be good reason to prefer this slightly overbroad per se rule to a case-by-case assessment of discriminatory effect in this context.

In constitutional law, as elsewhere, the use of an overbroad per se rule is generally justified on the basis that a more traditional case-by-case approach would not produce an optimal level of enforcement. ${ }^{119}$ Typically, the Court will reason that the individual right at stake is an important one, ${ }^{120}$ that violations of it are likely to occur with considerable frequency in this particular setting, ${ }^{121}$ that it is difficult for courts to identify those violations

118. For example, it is entirely possible that some or all of the district's residents will not fecl stigmatized by their assignment to it, that its representative will not believe that his or her primary obligation is to represent only the members of one racial group, and that its residents will in fact have some common political interests. If so, then the special stigmatic and representational harms that the Court describes will not be inflicted upon all of its residents.

119. See Schulhofer, supra note 20, at 450-51; Strauss, supra note 20, at 192-93.

120. See, e.g., Miranda v. Arizona, 384 U.S. 436, 457-58 (1966) (emphasizing the importance of the Fifth Amendment right at issue).

121. See id. at 445-58, 467 (explaining why police officers engaged in custodial interrogation are likely to violate this right on a regular basis). In the context of custodial interrogation, the high frequency of violations is a function not only of the fuzziness of the relevant constitutional standard, but also of the pressures that the relevant state actors face. Police officers engaged in custodial interrogation face considerable pressure from the public and their superiors to solve crimes. As a result, they constantly are tempted to cross the constitutional line in extracting confessions from suspects. 
on a case-by-case basis, ${ }^{122}$ and that adhering to the traditional case-by-case approach therefore will mean that many violations of the right will go unremedied. The Court will acknowledge that replacing case-by-case inquiry with an overbroad per se rule will produce some error in the other direction, which will have some social cost. ${ }^{123}$ But it will reason that some degree of error is unavoidable in any enforcement scheme, and that it is better, given the importance of the right, to err on the side of overenforcement than of underenforcement. ${ }^{124}$ In addition, it may note that the adoption of an overbroad per se rule will have some added benefits, such as producing a substantial savings in litigation costs, ${ }^{125}$ leading to more predictable results, ${ }^{126}$ and giving the relevant state actors an incentive to modify their behavior in ways that will reduce the number of violations they commit in the first place. ${ }^{127}$

The overbroad per se rule embedded in the Shaw doctrine can be justified on these familiar grounds. The individual right at stake here- - the right not to be singled out for special disadvantage because of one's race in the absence of a truly compelling justification-is one that virtually everyone regards as very important. State actors engaged in race-conscious districting are likely to violate that right with considerable frequency. ${ }^{128}$

122. See, e.g., Berkemer v. McCarty, 468 U.S. 420,433 \& n.20 (1984) (explaining that Miranda was in part a reaction to the difficulty courts had experienced with case-by-case assessment of compulsion in the context of custodial interrogation).

123. See, e.g., Withrow v. Williams, 507 U.S. 680, 703 (1993) (O'Connor, J.. concurring in part and dissenting in part) (noting that Miranda's per se rule imposes significant costs upon society because it requires the suppression of some confessions that are not the product of unconstitutional coercion, which impairs the administration of justice by concealing highly probative and reliable evidence from the trier of fact).

124. See, e.g., New York v. Quarles, 467 U.S. 649, 656-57 (1984) (describing the Miranda majority as engaging in this sort of reasoning). In addition to increasing the number of violations that are remedied ex post, an overbroad per se rule will tend to reduce the number of violations that occur ex ante, by changing the cost-benefit calculus that state actors will employ in deciding how to act.

125. See, e.g., Duckworth v. Eagan, 492 U.S. 195, 209 (1989) (O'Connor, J., concurring) (stating that the overbreadth of the Miranda rule can be defended on the ground that it facilitates "efficient judicial administration of the Fifth Amendment guarantec"): Berkemer, 468 U.S. at 433 (asserting that one objective of Miranda's per se rule is "to free courts from the task of scrutinizing individual cases to try to determine, after the fact, whether particular confessions were voluntary").

126. See, e.g., Berkemer, 468 U.S. at 430 (stating that one of the chicf vinues of Miranda's per se rule is its clarity, which makes it easy for both police officers and reviewing couns to apply).

127. See, e.g., Miranda v. Arizona, 384 U.S. 436, 444, 467, 476, $478-79$ (1966); see also Withrow, 507 U.S. at 702-03 ( $\mathrm{O}^{\prime}$ Connor, J., concurring in part and dissenting in part) (arguing that Miranda's overbreadth can be defended on the basis that it "provides a strong incentive for the police to adopt 'procedural safeguards' against the exaction of compelled or involuntary statements" (citation omitted)); Quarles, 467 U.S. at 656 (observing that "[t]he Miranda decision was based in large part on this Court's view that the wamings which it required police to give to suspects in custody would reduce the likelihood that the suspects would fall victim to constitutionally impermissible practices of police interrogation").

128. As in the Miranda context, the high probability of violations is a function not only of the fuzziness of the relevant constitutional standard, but also of the pressures that the relevant state 
Identifying those violations on a case-by-case basis is difficult for courts because of the subtle and abstract nature of the special harms involved. ${ }^{129}$ Given the frequency with which these violations are likely to occur and the difficulty of detecting them, a case-by-case approach is likely to mean that many violations will go unremedied. While replacing the traditional caseby-case approach with an overbroad per se rule will result in some error in the other direction, this is a cost worth bearing given the importance of the right. Substituting an overbroad per se rule for case-by-case inquiry into discriminatory effect will produce other benefits as well: It will reduce litigation costs, produce more predictable results, and encourage the relevant state actors to modify their behavior in a way that may reduce the number of violations they commit in the first place (complying with its traditional districting principles). ${ }^{130}$ In addition, it will have the virtue of preventing the courts from being used as a forum for the expression and validation of racial prejudices. Absent the per se rule, equal protection challenges to race-conscious districting plans would involve white plaintiffs testifying that they feel stigmatized by being placed in districts that are majority black, or that they believe that their representative does not adequately consider their interests because he or she is too busy trying to further the interests of their black neighbors. To a Court concerned about fanning the flames of racial prejudice and racial division, as this one clearly is, that surely is an unattractive prospect.

\section{Oddities Explained}

If, as I have suggested, we view the limitations that Shaw imposes on race-conscious districting as a prophylaxis of sorts, then many of the otherwise puzzling positions that the Court has taken in these cases make a good deal more sense. We can understand, for example, why the Court, speaking through Justice O'Connor, has insisted that the cause of action recognized in Shaw is designed to redress individualized harm to some subset of the state's residents, ${ }^{131}$ even though it does not require proof that the plaintiff is in fact being subjected to any such harm. The Court is not

actors face. State legislatures engaged in race-conscious districting face considerable pressure from the U.S. Department of Justice, powerful racial minorities within the legislature, and amended section 2 of the Voting Rights Act to draw plans that will ensure some degrec of minority electoral success. For this reason, they constantly are tempted to cross the constitutional line in designing districts.

129. Cf. United States v. Hays, 515 U.S. 737, 744 (1995) (noting that "[d]emonstrating ... individualized harm ... may not be easy" in this context).

130. See Bush v. Vera, 517 U.S. 952, 985 (1996) (plurality opinion) (noting that Shaw has had the salutary effect of encouraging legislators nationwide to modify their practices 10 "reembrace[] the traditional districting practices that were almost universally followed before the 1990 census").

131. See Hays, 515 U.S. at 744; Shaw I, 509 U.S. 630, 649-50 (1993). 
requiring proof of that harm, because it is presuming its existence from other facts that it is requiring the plaintiff to prove: specifically, that he resides in a district that was constructed predominantly on the basis of race, in substantial disregard of certain traditional districting principles.

So too can we understand why the Court, through Justice O'Connor, has insisted that compliance with its traditional districting principles is not constitutionally required, ${ }^{132}$ even as it has cited a state's failure to do so as grounds for invalidating its districting plan on constitutional grounds. If Shaw is like Miranda, then failure to comply with those districting principles in designing a particular district is not a violation of the Constitution, in and of itself; ${ }^{133}$ it is simply a fact that, when combined with evidence that race was intentionally taken into account in the districting process, gives rise to a conclusive presumption that the district's residents are being subjected to special stigmatic and representational harms. Compliance with Shaw's traditional districting principles therefore is not constitutionally required as such, just as the administration of Miranda warnings is not. ${ }^{134}$ It is merely a precautionary measure that the Court is urging state actors to take in order to reduce the number of constitutional violations that race-conscious districting will produce. ${ }^{135}$

Finally, and most significantly, we can understand why the Court has held that the strict scrutiny of Shaw does not apply whenever the state intentionally takes race into account in districting, but only when it makes race the "predominant factor" in the districting process, "subordinat[ing] traditional . . . districting principles ... to racial considerations." ${ }^{136}$ Justices

132. See Vera, 517 U.S. at 962 (plurality opinion) (asserting that " [ 1 ]he Constitution does not mandate regularity of district shape"); Shaw I, 509 U.S. at 647 (stating thal compliance with traditional districting criteria like "compactness, contiguity, and respect for political subdivisions" is "not . . . constitutionally required").

133. See Oregon v. Elstad, 470 U.S. 298, 310 (1985) ("The failure of police to administer Miranda warnings does not mean that the statements received have actually been coerced."); New York v. Quarles, 467 U.S. 649, 655 n.5 (1984) ("[T] the failure to provide Miranda wamings in and of itself does not render a confession involuntary.").

134. See Quarles, 467 U.S. at 654; Michigan v. Tucker, 417 U.S. 433. 444 (1974): Miranda v. Arizona, 384 U.S. 436, 467 (1966). Of course, there are those who maintain that the Constitution does in fact require the administration of Miranda warnings. See, e.g., Elstad, 470 U.S. at 318-20 (Brennan, J., dissenting); id. at 367-68 (Stevens, J., dissenting); Tucker, 417 U.S. at 462-63 (Douglas, J., dissenting). But the members of the Shaw majority never have been among them. See, e.g., Withrow v. Williams, 507 U.S. 680, 702 (1993) (O'Connor, J., concuring in part and dissenting in part) (asserting that "Miranda's warnings requirement is not a dictale of the Fifth Amendment itself'); Minnick v. Mississippi, 498 U.S. 146. 160 (1990) (Scalia. J., dissenting); Duckworth v. Eagan, 492 U.S. 195, 209 (1989) (O'Connor, J., joined by Scalia, J., concurring) ("The Miranda rule is not, nor did it ever claim to bc, a dictate of the Fifth Amendment."); Tucker, 417 U.S. at 444.

135. Cf. Quarles, 467 U.S. at 656 ("The Miranda decision was based in large part on this Court's view that the wamings which it required ... would reduce the likelihood that the suspects would fall victim to constitutionally impermissible practices ....").

136. Miller v. Johnson, 515 U.S. 900, 916 (1995); see also Vera. 51\% U.S. at 958-59, 962-63 (plurality opinion); id. at 993 (O'Connor, J., concurring); Miller, 515 U.S. at 928 (O'Connor, J., concurring). 
Scalia, Kennedy, and Thomas, who seem to have accepted this limitation on the scope of Shaw only grudgingly, ${ }^{137}$ have characterized it as nothing but an effort to implement the discriminatory-purpose requirement of Washington v. Davis. ${ }^{138}$ So understood, the limitation is indeed difficult to defend. For years, the Court has insisted that Davis does not require proof that race was the "predominant" reason for the challenged decision, just proof that race was "a motivating factor" behind it. ${ }^{139}$ As the Court has explained, it can " $[r]$ arely ... be said that a legislature . . operating under a broad mandate made a decision motivated solely by a single concern, or even that a particular purpose was the 'dominant' or 'primary' one," ${ }^{140}$ and "[t]he search for legislative purpose is ... elusive enough, without a requirement that primacy be ascertained." ${ }^{141}$ If the Court intended Miller to carve out a special exception to the usual race-a-motivating-factor test for Shaw claims, it offered no justification for doing so. And, as others have explained, a "predominant purpose" test is particularly unworkable in the redistricting context. ${ }^{142}$

If, on the other hand, we understand the "predominant factor" limitation as an attempt to confine the scope of a conclusive presumption or per se rule on discriminatory effect, ${ }^{143}$ then it makes a good deal more

137. Indeed, the questions that these Justices asked in oral argument in Hunt v. Cromartie. 526 U.S. 541 (1999), suggested that they were prepared to abandon this limitation. See Official Transcript of Oral Argument Before the United States Supreme Court at 15-19, 43-45, Cromartie (No. 98-85), available in 1999 WL 31144.

138. 426 U.S. $229,239-48$ (1976) (holding that a racially discriminatory purpose or intent is a necessary element of an equal protection violation). For examples of these Justices describing the "predominant factor" limitation as nothing but an effort to implement the Washington v. Davis purpose requirement, see Justice Thomas's opinion for the Court in Cromartie, $119 \mathrm{~S}$. Ct. at 1549 (Thomas, J., for the Court); his concurring opinion in Vera, 517 U.S. at 999-1003, which Justice Scalia joined; and Justice Kennedy's opinion for the Court in Miller, 515 U.S. at 912-13, 915-16. For academic commentary to the same effect, see, for example, Briffault, supra note 54, at 50-57; and Pildes, supra note 18, at 2506-07. Pildes describes Miller's "predominant factor" test as a "motive-based" approach and an "intent standard" that "import[s] Washington v. Davis . . into redistricting." Pildes, supra note 18, at 2506-07.

139. Village of Arlington Heights v. Metropolitan Hous. Dev. Corp., 429 U.S. 252, 265-66 (1977). Precisely for this reason, the plaintiffs in North Carolina's most recent racialgerrymandering case asked the U.S. Supreme Court to replace the Miller race-the-predominantfactor test with the more traditional Arlington Heights race-a-motivating-factor test. See Appellee's Brief on the Merits at 19, Cromartie (No. 98-85), available in 1998 WL 865623.

140. Arlington Heights, 429 U.S. at 265.

141. Id. at $265 \mathrm{n} .11$ (internal quotation marks and citation omitted) (quoting McGinnis v. Royster, 410 U.S. 263, 276-77 (1973)).

142. For an explanation of why this is so, see, for example, Bush v. Vera, 517 U.S. 952. 1059-62 (1996) (Souter, J., dissenting); Pildes, supra note 18, at 2545-47; and Pildes \& Niemi, supra note 100, at 585-86. For further criticism of Miller's "predominant factor" test, sec Briffault, supra note 54, at 50-51, 56-57; Issacharoff, supra note 52, at 55-60; and Karlan, supra note 11 , at $300-06$.

143. Justice $O$ 'Connor's opinions in this area strongly suggest that she sees the "predominant factor" limitation as performing some function other than simply implementing the Davis purpose requirement. In her brief concurrence in Miller, which was devoted entirely to this limitation, she never used the terms "motive," "intent," or "purpose." See Miller, 515 U.S. at 928-29 (O'Connor, J., concurring). In her plurality opinion in Vera, she firmly rejected the argument that 
sense. As explained above, the special stigmatic and representational harms that the Court has said race-conscious districting can inflict upon individuals are likely to be suffered only by residents of districts that have been constructed predominantly on the basis of race, in substantial disregard of certain traditional districting principles. ${ }^{\text {lt }}$ By requiring a plaintiff to make this showing in order to trigger the strict scrutiny of Shaw, then, the Court is simply restricting its conclusive presumption of discriminatory effect to situations in which there is a reasonable likelihood that the plaintiff has in fact suffered the special harms it is presuming. ${ }^{\text {th }}$

This is not to suggest, as some have, ${ }^{146}$ that a state can completely immunize a race-conscious districting plan from strict scrutiny under the Equal Protection Clause by making sure that its lines comply with the traditional districting principles that the Court has identified. Indeed, the Miranda analogy suggests precisely the opposite. If compliance with those traditional districting principles is just a means of reducing the risk that race-conscious districting will result in violations of individual equal protection rights, then it should not completely insulate a plan from strict scrutiny under the Equal Protection Clause, any more than administration of Miranda warnings completely insulates a statement from Fifth Amendment

the state's neglect of traditional districting principles was relevant only as circumstantial evidence of its racial motivation, insisting that it was also, and more fundamentally, "part of the constitutional problem." Vera, 517 U.S. at 981 (plurality opinion). She insisted that proof that the state had intentionally designed the challenged district to have a certain racial makeup was not sufficient to satisfy the "predominant factor" requirement, see id. at 958-59, 962 (plurality opinion); id. at 993 ( $\mathrm{O}^{\prime}$ Connor, J., concurring), even though, as Justice Thomas pointed out it would have been sufficient to characterize the state's action as racial gerrymandering. See id. at 1001 (Thomas, J., dissenting). All of this suggests that she may understand the "predominant factor" limitation as performing some function other than simply implementing the Davis purpose requirement. Cf. Issacharoff \& Goldstein, supra note 13, at 66 (remarking that "the legislature's mindset" does not appear to be "the focus" of Justice O'Connor's analysis).

144. See supra notes $97-102,106-110$ and accompanying text.

145. See Shaw II, 517 U.S. 899, 931 (1996) (Stevens, J., dissenting) ("This higher threshold for triggering strict scrutiny comports with the fact that the shared representational and stigmatic harms that Shaw purports to guard against are likely to oceur only when the State subordinates race-neutral districting principles to a racial goal." (citing Shaw I. 509 U.S. 630, 646-49 (1993))). On this view, the degree to which race has infected the districting process is important not for what it says about the possibility that the law has an improper purpose, but for what it says about the law's likely effect. I do not mean to suggest that Shaw claims are exempt from the Davis purpose requirement. They plainly are not. Indeed, the bulk of the Cour's opinion in Shaw $l$ was devoted to explaining that the requirement can be satisfied by circumstantial evidence like the shape and racial demographics of the challenged district. My point is simply that the "predominant factor" limitation the Court added to the Shaw doctrine in Miller may go primarily to the question of discriminatory effect, rather than discriminatory purpose. Cf. Pildes, supra note 18, at 2507 (noting that the Cour has begun to decide Shaw cases "in ways that cannot be reconciled with a primary emphasis on ferreting out legislative intenl"); id. at 2547. 2549 (citing the Court's approval of a deliberately drawn majority-minority district in DeWitt v. Wilson, $856 \mathrm{~F}$. Supp. 1409 (E.D. Cal. 1994), aff'd, 515 U.S. 1170 (1995)).

146. See Shaw II, 517 U.S. at 932 (Souter, J., dissenting) (suggesting that Miller "demonstrates that ... States may avoid strict scrutiny by complying with traditional districting principles"); cf. Pildes, supra note 18, at 2541 (suggesting that the Court should impose strict scrutiny only when a state has departed "unreasonably" from traditional districting principles). 
challenge. ${ }^{147}$ It should deprive a plaintiff of the ability to use Shaw's per se rule to establish the discriminatory effect required to trigger strict scrutiny, just as the administration of Miranda warnings deprives a criminal defendant of the ability to use Miranda's per se rule to establish coercion. ${ }^{148}$ But the plaintiff should remain free to establish that element of his equal protection claim, and to trigger strict scrutiny, by more conventional means: by presenting evidence that the plan does in fact subject him to some kind of special harm. ${ }^{149}$

\section{E. Unfinished Business}

If Shaw and its progeny establish a per se rule that overprotects individual constitutional rights in some cases in order to ensure adequate enforcement of those rights across a range of cases, then there is one striking difference between that per se rule and the one that the Court crafted in Miranda. The Miranda rule is quite specific, while the Shaw rule is not. When the Court promulgated a per se rule in Miranda, it defined the contours of that rule with considerable precision. In addition to stating that it would apply the rule to any statement made during a custodial interrogation that had been conducted without the prior administration of certain warnings, it described those warnings in such detail ${ }^{150}$ that it was criticized for legislating from the bench. ${ }^{151}$ In retrospect, however, Miranda's specificity has emerged as one of its chief virtues. ${ }^{152}$ Because the

147. See Berkemer v. McCarty, 468 U.S. 420,433 n.20 (1984) (noting that compliance with the Miranda warnings requirement will not "conclusively establish[] the voluntariness of a subsequent confession").

148. See id.

149. Cf. New York v. Quarles, 467 U.S. 649, 655 n.5 (1984) (noting that a defendant who is not entitled to Miranda's presumption of coercion can still have his confession excluded on Fifth Amendment grounds if he provides actual evidence of coercion). On this view, the Court's muchmaligned insistence that its decision in Shaw is not inconsistent with its earlier decision in United Jewish Organizations v. Carey (UJO), 430 U.S. 144 (1977), see Shaw I, 509 U.S. at 651-52, seems a good deal more plausible. As Justice O'Connor explained in Shaw I, the districts challenged in $U J O$, though deliberately drawn to give a certain racial group a majority, complicd with the traditional districting principles that the Court identified in Shaw. See id. at 651. As a result, the plaintiffs in UJO were not entitled to Shaw's conclusive presumption of special disadvantage, and could trigger strict scrutiny only by producing actual evidence that the challenged lines actually subjected them to some special disadvantage. Because they failed to do so, the Court properly rejected their equal protection challenge.

150. See Miranda v. Arizona, 384 U.S. 436, 468-73 (1966) (holding that the suspect must be clearly informed "that he has the right to remain silent," "that anything [he says] can and will be used against [him] in court," "that he has the right to consult with a lawyer and to have the lawyer with him during interrogation," and "that if he is indigent a lawyer will be appointed to represent him").

151. See, e.g., HENRY J. FRIENDLY, BENCHMARKS 278 (1967) (criticizing the Court for "utilizing the Bill of Rights to prescribe a detailed code of criminal procedure").

152. The Court has recognized this on numerous occasions. For some prominent examples, see Arizona v. Roberson, 486 U.S. 675, 680-82 (1988); Berkemer, 468 U.S. at 430; and Fare v. Michael C., 442 U.S. 707, 718 (1979). 
Court has defined the contours of the per se rule so precisely, state actors have little doubt about what they must do to avoid triggering it, and courts reviewing their conduct after the fact have little doubt about when they should apply it. ${ }^{153}$ The result has been a substantial degree of compliance with the Fifth Amendment ex ante ${ }^{154}$ and a substantial reduction in the administrative costs incurred to enforce the Fifth Amendment ex post. ${ }^{15 s} \mathrm{~A}$ less specific rule would not have produced these benefits.

As currently formulated, the per se rule that the Court has crafted in Shaw is much less precise. The Court has indicated that the rule applies whenever the state has used race as the "predominant factor" in the design of the challenged district, "subordinat[ing] traditional race-neutral districting principles ... to racial considerations." " 156 But this formulation contains all sorts of ambiguities and uncertainties. What are the traditional districting principles to which the Court refers? How is compliance with those districting principles to be measured? And how much compliance with them is necessary to establish that they have not been "subordinated" to race? Absent these specifics, the rule that the Court has promulgated is much like one that says the police should give suspects warnings before interrogating them, but fails to specify the precise content of those warnings.

The Court's lack of precision prevents Shaw's per se rule from realizing some of its most significant potential benefits: increasing compliance with the Constitution ex ante and reducing the administrative costs of enforcing the Constitution ex post. Because state actors cannot tell with any certainty what the rule requires of them, the rule is unlikely to produce a substantial increase in their compliance with the Constitution. And because courts reviewing their conduct after the fact cannot tell with any certainty when to apply the rule, the rule is unlikely to produce a substantial savings in administrative costs.

153. See Fare, 442 U.S. at 718 (acknowledging that Miranda "has the virtue of informing police and prosecutors with specificity as to what they may do in conducting custodial interrogation, and of informing courts under what circumstances statements obtained during such interrogation are not admissible," and that this "specificity . . benefits the aceused and the State alike").

154. Cf. Louis Kaplow, Rules Versus Standards: An Economic Analysis, 42 DUKE L.J. 557 (1992) (explaining that when a legal command is expressed as a rulc that individuals can apply with little difficulty, individuals will be more likely to choose to conform their conduct to the law than they will when it is expressed as a standard that will be given content only after they act).

155. Miranda's per se rule reduces the costs of enforcing the Fifth Amendment ex post in two ways. First, it reduces the number of violations that occur by encouraging police officers to modify their conduct in ways that will produce fewer violations. Second. it reduces the amount of time and effort that courts and litigants must spend identifying and redressing those violations that do occur.

156. Miller v. Johnson, 515 U.S. 900,916 (1995); see also Bush v. Vers. 517 U.S. 952, 958 65 (1996) (plurality opinion); id. at 993 (O'Connor, J., concurring); Shaw II. 517 U.S. 899, 905-07 (1996); Miller, 515 U.S. at 928 (O’Connor, J., concurring). 
To make Shaw's per se rule realize its true potential, the Court must give it greater precision. In particular, the Court needs to explain exactly what state actors must do in order to avoid triggering it. The best, and perhaps only, way for the Court to do this is to replace Miller's vague "predominant factor" test with a rigid rule that the strict scrutiny of Shaw applies only to districts that not only are the product of a districting process in which race was intentionally considered, but that also fail to comply with certain clearly identified districting principles. ${ }^{157}$

This would mean replacing the amorphous and potentially open-ended term "traditional districting principles" with a finite list of districting criteria that have specific and objective content. For example, the Court might say that the districts must be contiguous and that they must have a dispersion-compactness score of at least $0.24^{158}$ and a perimetercompactness score of at least $0.12 .{ }^{159}$ As others have noted, ${ }^{160}$ such a step would be analogous to what the Court did in Reynolds $v$. Sims ${ }^{161}$ and its

157. See Vera, 517 U.S. at 1057, 1070-72, 1077 (Souter, J., dissenting) (arguing that this is the only way for the Court to make Shaw manageable, unless it is prepared to eliminate the practice of geographic districting altogether or to require that districting be done on a completely random basis); Pildes, supra note 18, at 2547-51 (urging the Court to do this); see also Aleinikoff \& Issacharoff, supra note 93, at 621 (calling this a "possible" solution to "the ambiguity of Shaw").

158. The dispersion-compactness measure attempts to capture "how tightly packed or spread out the geography of a district is." Richard G. Niemi et al., Measuring Compactness and the Role of a Compactness Standard in a Test for Partisan and Racial Gerrymandering, 52 J. POL. 1155. 1160 (1990). A district's dispersion-compactness score is the ratio of the area of the district to the area of the smallest circle that completely encloses the district. See Pildes \& Niemi, supra note 100 , at 554. A district that is a perfect circle has a dispersion-compactness score of 1.0. See id. at 555. Districts that are long and narrow, or have numerous appendages radiating from a central core, will have lower dispersion-compactness scores than those with relatively square shapes. See id. at 554. The two districts challenged in Shaw I, Districts 1 and 12 in North Carolina's 1991 congressional redistricting plan, had dispersion-compactness scores of 0.25 and 0.05 , respectively. See id. at 562 tbl.2. For a look at some other congressional districts of the 1990s with dispersioncompactness scores of less than 0.24, see $i d$. at 547-48 figs.3(d)-(f).

159. The perimeter-compactness measure attempts to capture "the extent to which [a] district's borders wander in irregular ways." Pildes \& Niemi, supra note 100, at 555. A district's perimeter-compactness score is the ratio of the district's area to the area of a circle with the same perimeter. See id. at 555; Daniel D. Polsby \& Robert D. Popper, The Third Criterion: Compactness as a Procedural Safeguard Against Partisan Gerrymandering, 9 YALE L. \& POL'Y REV. 301, 348-49 (1991) (referring to this as "the Schwartzberg measure"). A district that is a perfect circle will have a perimeter-compactness score of 1.0. See Pildes \& Niemi, supra note 100 , at $555 \mathrm{n} .203$. Districts with highly irregular borders will have lower perimeter-compactness scores than those with more regular shapes. See id. at 556. Districts 1 and 12 in North Carolina's 1991 congressional redistricting plan had perimeter-compactness scores of 0.03 and 0.01 , respectively. See id. at 562 tbl.2. For a look at some other congressional districts of the $1990 \mathrm{~s}$ with perimetercompactness scores of less than 0.12 , see id. at $544-45$ figs.2(e)-(g).

160. See Aleinikoff \& Issacharoff, supra note 93, at 621-22; Pildes \& Niemi, supra note 100. at $586-87$.

161. 377 U.S. 533 (1964). 
progeny, when it translated the vague mandate of Baker v. Carr ${ }^{162}$ into the crude but easily administered "one person, one vote" rule.

Why has the Court not done this already? There are at least two possible reasons. First, the Court may be concerned that particularizing Shaw in this way would be inconsistent with its longstanding position that the Constitution does not require the states to comply with traditional notions of compactness and contiguity. ${ }^{163}$ Second, it may regard itself as institutionally ill-suited to the task of formulating specific rules of district shape, a task that seems quintessentially legislative in nature.

The first concern is easily answered. Under the view of Shaw that I have suggested here, the Court would not be promulgating constitutional rules on district shape with which every state in the country would be required to comply. Instead, it would be developing subconstitutional districting principles for states engaged in race-conscious districting to follow-principles that, if followed, would enable those states to avoid Shaw's per se rule. ${ }^{164}$ Compliance with those districting principles would not be constitutionally required, just as the administration of Miranda warnings is not. Rather, it would be a safe harbor of sorts for states engaged in race-conscious districting-a way to deny those who would mount equal protection challenges to their plans the ability to rely on Shaw's conclusive presumption of discriminatory effect.

The second concern has more force. Indeed, at first glance, the concern about institutional competence seems more compelling here than it was in Miranda. Most judges are, by virtue of their own professional experience, quite familiar with the dynamics of police work, at least as familiar as their colleagues in the legislatures. When it comes to formulating code-like rules to govern custodial interrogation, then, there is little reason to suspect that legislatures will do a better job than courts. Redistricting, on the other hand, is a matter with which legislatures have much more experience than courts, and it seems logical to assume that they will be better than courts at developing specific rules to govern it.

Upon closer examination, though, the institutional competence concern is less compelling. While legislatures may have more experience with redistricting than courts, their members are the very people who have the greatest stake in the precise content of the legal rules that govern the

162. 369 U.S. 186 (1962) (holding that malapportionment of a state legislature can violate the Equal Protection Clause, without explaining precisely when that might be so).

163. See Aleinikoff \& Issacharoff, supra note 93 , at 623 (calling this "[t]he major problem" with this solution to the vagaries of Shaw). The Miranda Coun did not have to deal with this difficulty. At the time Miranda was decided, there was no preexisting body of case law holding that the specific precautionary measures that the Court was announcing were not constintionally required.

164. As Rick Pildes has pointed out, this is precisely what lower courts applying Shaw seem to be doing in practice, whether they acknowledge it or not. See Pildes, supra note 18, at 2549-50. 
redistricting process. Precisely for this reason, they are less competent than the courts-indeed, uniquely incompetent-to formulate code-like rules to govern that process. Indeed, the courts would seem to be the only institution of government that is sufficiently disinterested to be entrusted with the task.

\section{CONCLUSION}

In this Essay, I have argued that the restrictions that the Court has imposed on race-conscious districting in Shaw and its progeny may be an example of a phenomenon that is pervasive in our constitutional law: the crafting of prophylactic rules that overprotect individual constitutional rights in some cases in order to ensure adequate enforcement of those rights across a range of cases. I do not contend that this is the only plausible explanation for the Court's work here, just that it is one plausible explanation, more plausible than any that has been offered to date. On this view, Shaw and its progeny are nowhere near as radical as the Court's critics on the left would have us believe. Nor is the doctrine that the Court has constructed in Shaw as intellectually incoherent as its critics-both left and right-have suggested.

What are the implications of this understanding of Shaw? In terms of the future development of the Shaw doctrine, it means that there is a good deal more room to maneuver here than most of us have assumed. If Shaw is in fact just a prophylactic measure like Miranda, then litigants should feel free to ask courts to devise additional prophylactic rules to supplement it when doing so would help safeguard the underlying equal protection rights. ${ }^{165}$ By the same token, litigants should feel free to ask courts to carve out exceptions to Shaw's per se rule in situations in which the rule's costs outweigh its benefits. ${ }^{166}$

On a broader jurisprudential level, this understanding of Shaw suggests that the drive toward colorblindness that we have seen in the Court's equal

165. In the years since Miranda was decided, the Court has announced a number of other prophylactic rules that provide additional layers of protection for the underlying constitutional right. For a prominent example, see Edwards v. Arizona, 451 U.S. 477 (1981), which adopted a per se rule that once a suspect has invoked his right to have counsel present during custodial interrogation, further interrogation may not take place unless the suspect himself initiates it. The Court has described the Edwards rule as a "prophylactic" measure that works together with the Miranda rule to safeguard the Fifth Amendment privilege against self-incrimination by discouraging the police from badgering suspects into waiving their right to remain silent. See Michigan v. Harvey, 494 U.S. 344, 350 (1990); Oregon v. Bradshaw. 462 U.S. 1039. 1044 (1983) (plurality opinion).

166. Since Miranda was decided, the Court has employed this sort of cost-benefit analysis to justify creating a number of exceptions to its per se rule. For a prominent example, see New York v. Quarles, 467 U.S. 649 (1984), in which the Court relied on cost-benefit analysis to justify recognizing a "public safety" exception to Miranda's warning requirement. See id. at 653-60. 
protection jurisprudence ${ }^{167}$ may not represent a radical, ahistorical reinterpretation of the core meaning of the Equal Protection Clause, as many have assumed. Instead, it may represent judicial activism of a different, and perhaps less pernicious, sort: the crafting of overbroad prophylactic rules designed to implement that core understanding. ${ }^{168}$ The Rehnquist Court, it seems, is conducting its revolution in race with tools borrowed from the Warren Court's revolution in constitutional criminal procedure. If so, then the pending challenge to Miranda ${ }^{169}$ may have ramifications far beyond the context of custodial interrogation.

167. The most obvious illustrations of this trend are the cases striking down race-based affirmative action programs. See, e.g., Adarand Constructors v. Peña, 515 U.S. 200 (1995); City of Richmond v. J.A. Croson Co., 488 U.S. 469 (1989). But the phenomenon is not limited to that context. See, e.g., Batson v. Kentucky, 476 U.S. 79 (1986) (invoking the Equal Protection Clause to invalidate the prosecution's use of race-based peremptory challenges in criminal cases).

168. Cf. Levinson, supra note 20, at 903-04 n.191 (suggesting that the Court's prohibition on race-based affirmative action can be seen as "a prospective, prophylactic remedy for an antisubordination equal protection right," rather than a recognition "that colorblindness is itself the goal of equal protection").

169. See United States v. Dickerson, 166 F.3d 667 (4th Cir.), cert. granted, 120 S. Ct. 578 (1999). 
